\title{
Review of botanical characterization, growth preferences, climatic adaptation and human health effects of Ericaceae and Empetraceae wild dwarf shrub berries in boreal, alpine and arctic areas
}

\author{
R. Nestby*, A.L. Hykkerud and I. Martinussen \\ Department of Horticulture, Norwegian Institute of Bioeconomy Research (NIBIO), \\ Division of Food Production and Society, Norway
}

Received 22 January 2019; accepted 8 March 2019

\begin{abstract}
.
BACKGROUND: Interest in the wild berries of dwarf shrubs (wild berries) is increasing. Therefore, an update is important regarding how these species react to and interact with different climatic factors, and on how the predicted climatic changes will affect their distribution, growth and content of compounds affecting health.

OBJECTIVE: To systemize knowledge of the Ericaceae and Empetraceae wild berry species.

METHODS: A review of literature covering the above topics.

CONCLUSION: This review includes five wild berry species and their subspecies: Vaccinium myrtillus, Vaccinium vitisidaea, Vaccinium uliginosum, Vaccinium oxycoccos with ssp. microcarpon, and Empetrum nigrum with ssp. nigrum, hermaphroditum and japonicum. They have been and still are collected in the wild, by local households and industry. The berries have high content of biological compounds of interest for human health. Despite the increasing interest in and demand for these wild berries, domestication attempts have been rare. The species often grow together and are competitors. Which species dominate depends on soil conditions and is determined by small differences. The changing climate and various disturbances will also influence the distribution patterns of wild berries and competing plant species. Semi-cultivation in the natural habitat is probably the best solution for viable and sustainable commercial exploitation of these resources, at least if they are sold with the label "wild berries". However, these species are easily propagated by fresh cuttings, and they can grow on arable land, adapting soil conditions to fit their growing preferences. Such cultivation, to our knowledge has not yet been performed on a large economic scale.
\end{abstract}

Keywords: V. myrtillus, V. uliginosum, V. oxycoccos, V. vitis-idaea, E. nigrum, breeding, drought, freezing, UV-B, disturbance

\section{Introduction}

Interest in wild berries from dwarf shrubs (later termed wild berries) is strong and is increasing among consumers and industry in the Nordic countries. Simultaneously, there is a discussion on how to improve the

\footnotetext{
${ }^{*}$ Corresponding author: R. Nestby, Norwegian Institute of Bioeconomy Research (NIBIO); Division of Food Production and Society Department of Horticulture, P.O. Box 115, NO-1431 Ås, Norway. E-mail: rolf.nestby@nibio.no.
} 
utilization of resources, which are low and require improvement in accessing forest fields, improving yield and harvest conditions, given that every autumn $90-95 \%$ of the wild berry crop remains unpicked in Nordic forests [1]. In Finland alone, 36 wild berry species yielded in 2009 more than 900 million $\mathrm{kg}$. The major contributors are crowberry (Empetrum nigrum plus E.n. hermaphroditum), lingonberry (Vaccinium vitis-idaea), European blueberry (Vaccinium myrtillus), cranberry (Vaccinium oxycoccos plus V. oxycoccos ssp. microcarpum), cloudberry (Rubus chamaemorus) and bog bilberry (Vaccinium uliginosum) [2].

Accumulating scientific evidence on the health benefits of berries has led to an interest in the investigation of wild species for their therapeutic potential. In the Nordic countries, the development of wild berries depends on the geographic site and climatic conditions. Normally, wild berries ripen in July, August and September. In the Nordic countries, compared with lower latitudes, the growing season is short, the day lengths are much longer, and the temperature is lower during summer, thus profoundly affecting the phytochemical composition and content of the fruits [3]. Throughout history, wild berries have played an important role in the boreal, arctic and alpine areas in the northern hemisphere. In European history, the use of wild berries by humans living in northern Europe dates back about 750,000 years [4].

In Norway, the documentation of wild berries dates to 800 B.C. [5], when species such as wild raspberry (Rubus idaeus L.) and wild European blueberry (V. myrtillus L.) were mentioned in old writings [6]. Some species in the genus Vaccinium were domesticated in the 18th, 19th and 20th centuries [7]. Wild berries remain important in several areas north of the Tropic of Cancer $\left(23.5^{\circ} \mathrm{N}\right)$, and distribution maps are presented in later chapters addressing each species [8].

This review includes information on the botanical characterization, breeding, ethnobotany, growth factors and health benefits of wild berries, and of how a changing climate may affect their ecological adaption now and in the future.

\subsection{Breeding of wild berries}

In the wake of domestication, there has been interest in breeding and propagating selected clones of wild berries in Scandinavia, mainly in Finland and Norway. In Finland, the highbush blueberry 'Aron' was selected from the backcross 'Rancocas' ( $V$. corymbosum) x (V. uliginosum x 'Rancocas'). Vaccinium macrocarpon Ait., which is related to $V$. oxycoccos L., has been domesticated for less than 160 years, but native selections remain in use, and cultivated cranberry has scarcely evolved from its wild relatives. Breeding of the commercial cranberry (V. macrocarpon) has compromised plant defenses in high yielding cranberry cultivars, thus potentially leading to greater herbivore damage, which in turn might require more intensive pesticide control measures. Attention should be paid to avoiding similar mistakes in future breeding programs [9]. Wild Vaccinium vitis-idaea populations are variable in nearly all important horticultural traits $[10,11]$, thus favoring the possibility of breeding and selecting good clones. To select good clones of $V$. myrtillus, focus should be placed on the evaluation of qualitative and quantities results on compounds beneficial to health. These and future studies on the effects of the environment on berry quality should facilitate breeding specific clones for specific regions, and berries from the northern areas would add value because of their sweetness and higher content of health beneficial phenols [12].

\subsection{Biotic and edaphic conditions that may influence wild berries}

Wild berries grow in soils that are relatively low in nutrients and have podzolic or humus character, such as bogs. In arctic and sub-arctic areas, wild berries grow from sea level to above the treeline [13]. In the central and southern parts of the northern hemisphere, they generally grow in alpine areas [8, 14-19].

\subsubsection{Forest conditions and management}

Wild berries that grow in forest areas depend on the forest condition and management, such as light conditions, access to soil minerals and competition from trees. Timber felling, forest thinning or other interferences in growth 
conditions influence the development of wild berry species and their interactions. Semi-shade tolerant species such as $V$. myrtillus, decrease strongly after regeneration cutting of trees and recover slowly, but increase after intermediate cutting. Species adapted to semi-light conditions, such as V. vitis-idaea, strongly decrease after regeneration cutting but recover relatively quickly and increase after intermediate cutting. In contrast, lightdemanding species, such as E. nigrum, increase after regeneration cutting and decrease after intermediate cutting [20]. Species specific research has supplemented these findings, showing that in sites of a Betula pubescens forest in Norway, V. myrtillus and V. uliginosum showed little change over 3 years, whereas Empetrum spp. increased in number and frequency when the forest was cleared [21]. Another example in a northern taiga B. pubescens forest in Arkhangelsk, Russia, has shown that yields varied between 117 and $946 \mathrm{~kg} \mathrm{ha}^{-1}$ from 1984-1988, dependent on the year. V. uliginosum and V. myrtillus showed little change over 3 years regardless of whether the sites were cleared, whereas the number of $R$. chamaemorus plants increased when trees were felled [22]. Although several studies have shown large variations among plant communities in their short-term responses to environmental perturbations, Wardle et al. [23] have found different results. They have revealed that when perturbations apply equally to highly contrasting environments, differences in resilience in the long term (14 years) are relatively minor regardless of the severity of the disturbance.

\subsubsection{Airborne pollution}

Other conditions may influence growth and development and cause species interactions. In recent history, airborne pollution is one such condition. Relatively large amounts of sulfur $(\mathrm{S})$ and nitrogen $(\mathrm{N})$ transported through the air have influenced Nordic ecosystems by acidifying and adding $\mathrm{N}$ to the soil. Acidification can retard the decomposition of cellulose rich litter. The importance of adsorption of minerals from rainfall by leaves is probably minor, because uptake by plant roots appears to be the main source of nutrient elements as well as some non-essential elements in V. myrtillus and V. uliginosum [24].

Although wild berries prefer acidic soil, acid rain causes leaching, which may lead to nutrient deficiency and a release of toxic heavy metals, thereby affecting soil fertility and potentially decreasing plant growth [25]. However, heavy metals from wood ash or fertilizer application have not confirmed the potential negative effect [26]. In addition, because litter is the source of the humus layer and is important for some wild berries, the decreased decomposition of the humus layer as an effect of strong acidification may be important [24, 27]. Liming, used in forest management to decrease the effect of acid rain, has been found to result in distinct decreases in $\mathrm{NH}_{4} \mathrm{NO}_{3}$-extractable manganese $(\mathrm{Mn})$, zinc $(\mathrm{Zn})$ and lead $(\mathrm{Pb})$ in the humus layer 4 years after liming and fertilization [28].

However, since 1997, N deposition has declined 25\% across the southern half of Sweden, and $\mathrm{S}$ has declined by more than half [29]. Despite a strong decrease in acid and nutrient polluted rain as a result of governmental regulations [30], acid rainfall still remain an important environmental issue worldwide, lowering pH especially in light soils [31].

\subsubsection{Mineral nutrition}

Mycorrhiza are important for Vaccinium species and Empetrum, because ericoid-mycorrhiza colonize the roots of these species and support their uptake of mineral nutrients [32]. Ericaceous roots have been suggested to host diverse fungal communities dominated by Helotiales; nevertheless, these fungal communities are unlikely to be controlled by fungal host preferences alone.

Excess $\mathrm{N}$ from rainfall may be a problem. However, the effect on uptake of $\mathrm{NO}_{3}{ }^{-}$in a pristine Norwegian alpine catchment ecosystem, adding $7 \mathrm{~kg} \mathrm{~N} \mathrm{ha}^{-1}$ year $^{-1}$ as nitric acid, compared with the natural ambient input of $2 \mathrm{~kg} \mathrm{~N} \mathrm{ha}^{-1}$ year ${ }^{-1}$, revealed that the catchment retained $90 \%$ of the $\mathrm{NO}_{3}{ }^{-}$inputs for 9 years, similarly to the ambient input. The runoff contained high levels of nitrate only at high flow together with high concentrations of nitrate in incoming water. The $\mathrm{N}$ deposition did not induce $\mathrm{N}$ saturation, and retarded decomposition and higher total $\mathrm{N}$ concentration, thus indicating that part of the $\mathrm{N}$ may be stored in the ectoorganic layer. The $\mathrm{N}$ content in foliage did not reveal differences ascribed to $\mathrm{N}$ addition [33]. However, a general trend of decreased $\mathrm{N}$ 
resorption efficiency occurred in response to increased $\mathrm{N}$ supply. Relatedly, a species interaction was observed, thus showing that $\mathrm{P}$ resorption efficiency after $\mathrm{N}$ application did not change in E. nigrum ssp. hermaphroditum and Rubus chamaemorus, but increased in V. uliginosum [34]. Despite greatly decreased S deposition, due to emission controls, a long time lag has been suggested between emission abatement and changes in soil solution acidity, thus underlining the importance of long-term monitoring in evaluating ecosystem responses to decreases in deposition [35].

In 2015, in a fertilization experiment in subalpine tundra in northern Sweden initiated in 1989, Empetrum originally dominated, but the faster growing Deschampsia flexuosa replaced it. Regardless of whether Empetrum or Deschampsia were removed, few interactive effects appeared after fertilizer or plant removal treatment aboveground or belowground. The effect of fertilizer on most community and ecosystem properties operated independently of even large shifts in the plant community. This finding also suggests decoupling of aboveground and belowground communities in tundra and therefore offers insight into the mechanistic basis through which global change influences how soil nutrient availability may transform tundra ecosystems [36-39].

\subsection{Effects of biological compounds in wild berries on human health}

\subsubsection{Health effects}

Several studies support the health promoting benefits of berries, especially in managing aging and degenerative conditions such as Alzheimer's disease, cancer, heart disease, type II diabetes, kidney disorder, atherosclerosis, high blood pressure, stroke, visual impairment and skin disorders. Oxidative stress and the accumulation of advanced-glycation-end products are involved in the development of all these diseases [40]. Wild berry extracts decrease the formation of advanced-glycation-end products in a concentration-dependent manner that positively correlates with total phenolic content and, to a lesser degree, total anthocyanin content [41]. These processes are not fully understood but seem to be mainly related to interactions between phenolic compounds and several key enzymes; signaling cascades involving cytokines and regulatory transcription factors, and antioxidant systems $[42,43]$.

Frequent consumption of dietary antioxidants (among them polyphenols), on the basis of epidemiological studies on strawberries, have been found to provide protection against the occurrence of cancer, cardiovascular diseases, diabetes, osteoporosis and exogenous ethanol-induced damage to rat gastric mucosa [44-48]. Such effects probably also extend to the consumption of wild berries, although the profile of polyphenols varies between species. Moreover, strawberry consumption protects against doxorubicin induced toxicity at the plasma, liver and mitochondrial levels, owing to the high content of bioactive compounds. In addition, strawberries have antioxidant properties, and studies have provided new insights into the beneficial roles of strawberry bioactive compounds in protecting skin from oxidative stress and aging [47, 49]. A review article has summarized current knowledge of the anti-platelet activity of numerous berry species (black chokeberry, aronia, European blueberry, cranberry, sea buckthorn and grapes) as well as their juices, which make up an integral part of the human diet. The effects of these berries depend on the concentration and class of phenolic compounds and the type of product (e.g., fresh, juice or medicinal products). Studies have indicated that berries play a role in the prevention of cardiovascular disorders [50].

\subsubsection{Content of health-affecting biological compounds in wild berries}

High amounts of different phenolic compounds (anthocyanins, flavonols, flavan-3-ols, phenolic acids, proanthocyanidins and ellagitannins) and abscisic acid derivatives have been identified and quantified in wild Canadian V. vitis-idaea, V. uliginosum, E. nigrum and R. chamaemorus [51]. In Norway, the level of carbohydrates in wild

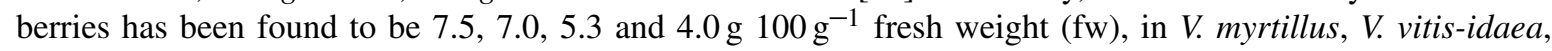
E. nigrum and $V$. oxycoccos, respectively [52]. The level of carbohydrates in berries of $V$. myrtillus has been found to be close to this level $\left(7.7^{\circ} \mathrm{Brix}\right)$, while total anthocyanins were $297.4 \pm 50 \mathrm{mg} 100 \mathrm{~g}^{-1} \mathrm{fw}$ [53]. Another study has revealed that the anthocyanin levels in extracts of $V$. uliginosum and $V$. vitis-idaea were slightly lower, 


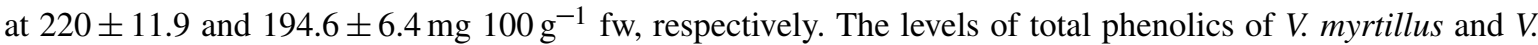
vitis-idaea were $504.5 \pm 32.2$ and $624.4 \pm 34.2 \mathrm{mg} 100 \mathrm{~g}^{-1} \mathrm{fw}$ [54, 55], thus confirming the above high values of anthocyanins and polyphenols in V. myrtillus vs V. vitis-idaea. These findings indicate the levels of anthocyanins and total phenols in wild berries. However, values reported in different studies may not be directly comparable, because they are biased by the time of harvest, cultivar and local and regional conditions.

The content of lipids in berries is low, but berry oils have become increasingly popular in health care because of their high content of unsaturated fatty acids and antioxidants [56]. Other substances found in berry seed oils are triterpenoids and sterols [57]. Both have anti-inflammatory, antiviral, wound-healing and anticarcinogenic properties [58]. One hundred and eleven lipids have been described in V. myrtillus, V. uliginosum, V. vitis-idaea, $R$. chamaemorus, E. nigrum, V. oxycoccos and V. corymbosum. The lipid fraction contains classes such as fatty acids, sterols, triterpenoids, alkanes, phenolic and carboxylic acids, and carotenoids [59].

Could the preferences of the brown bear (Ursus arctos) for wild berries indicate which berries are more important for humans concerning health effecst? A study by Stenset et al. (2016) has concluded that before hibernation, bears prefer $V$. myrtillus before E. nigrum ssp. hermaphroditum, and prefer both before V. vitisidaea [60]. Another study has confirmed the ranking between V. myrtillus and V. vitis-idaea [61]. Similarly, some European bird species show preferential feeding on berries with higher antioxidant contents [62, 63], a finding that may have important implications for the palatability, and therefore seed dispersal, of these species.

\subsection{Effects of climate change on phenotype and competition between species}

Wild berries such as E. nigrum are vulnerable to disturbance and climate change and are locally extinct or decreased in its habitats because of such effects. To cope with these effects, conservation measures are practiced at the national and/or state level in some countries such as the USA, Canada, Korea and China [64]. In contrast, an investigation of clonal diversity, genetic size structure and genetic longevity in four arctic-alpine plants, including V. uliginosum, has shown that the oldest genes of V. uliginosum are 1400 years old [65]. This result indicates that individuals have survived pronounced climatic oscillations, thus demonstrating that long-lived clonal plants in arctic-alpine ecosystems can persist, despite considerable climatic change, although changes in stands occur.

\subsubsection{Effects of temperature on flowering, fruiting, growth and spreading}

Flowering, growth and spreading of wild berries will be affected by the predicted temperature increase due to climate change. Several studies have indicated a scenario in which plants respond with physiological and/or phenological changes. Medium-term warming studies in cold biomes (sub-arctic Sweden) have shown changes in species composition and structure. These changes had much stronger defects than climate-change induced phenotypic responses on plant-mediated nutrient and carbon cycling pathways and rates, regardless of the seasonal timing of these climate changes [66]. These reactions were strengthened by findings of Tonteri et al. [20] indicating only slight signals from the effects of climate warming in a few species in a regenerative or intermediate cut forest. In the case of negative climatic effects, migration to new habitats may be a solution. A potential for migration to altitudes above current populations for V. myrtillus, V. vitis-idaea and V. uliginosum species has been described [67] in which $V$. myrtillus had the highest recruitment potential. A similar beneficial reaction of V. myrtillus was observed in a boreal coniferous forest in southern Norway in 1931, 1961 and 1991, where major changes occurred over that time. The long-term changes were a decreased frequency of species and of joint occurrences of vascular species, including V. myrtillus, V. uliginosum and V. oxycoccos. These changes were interpreted as being induced by internal processes, e.g., notably a long-term change from paludified to mesic forest. A dominance of Picea abies and V. myrtillus rendered the conditions more unfavorable for other species [68]. A strategy of these plants would be to move to habitats with a proper climate. This is possible, e.g., when predicting long-term range shifts in the Arctic, where unlimited dispersal of plant species is assumed to occur 
through propagules carried by wind and drifting sea ice. However, establishment limits distribution more than dispersal [69].

A study in Abisko, Sweden, has suggested that increasing temperature in combination with better availability of $\mathrm{N}$ makes deciduous shrubs such as $V$. myrtillus and $V$. uliginosum compete more efficiently over evergreen shrubs such as E. nigrum, which are outmatched [70]. Temperature increases generally promote shoot growth and meristem activation in wild berries. In a fellfield 1150 MASL in northern Sweden, temperature enhancement was found to explain more of the total experimental variance than fertilizer addition. However, at a heath 450 MASL in northern Sweden, shoot growth of dwarf shrubs was found to be largely unaffected by temperature changes: only V. uliginosum responded by activating new meristems. Better nutrient availability may possibly increase growth more than changes in temperature in climatically benign sites [71].

The year-to-year variations in wild berry yield can be dramatic in boreal forests. The variations have been linked to weather events, and therefore determining which weather events are critical because of global warming is important [72-74]. A Swedish study has concluded that natural levels of outcrossing are sufficiently high for full seed production and that the availability of pollen is not limiting in natural habitats of V. myrtillus, $V$. uliginosum, V. vitis-idaea and V. oxycoccos [75].

An increase in both soil and air temperature has been found to stimulate soil-N cycling and growth and development of $V$. myrtillus in the short term (2-3 years) [76]. Net $\mathrm{N}$ mineralization rates doubled in warmed soil in the second experimental year and contributed to a $62 \%$ increase in current year growth of V. myrtillus. After 3 years, shoot production increased by more than $80 \%$ in the evergreen wild berries V. vitis-idaea and $E$. nigrum hermaphroditum. In later years, there was no detectable effect of the treatment on plant growth or soil $\mathrm{N}$ cycling, thus suggesting that long-term responses may be less dramatic than short-term responses. Another study in a mid-latitude alpine ecosystem has revealed an increase in air temperature by $1.5-2.3^{\circ} \mathrm{C}$ over 5 years, which tended to increase the annual shoot growth and above ground mass accumulation of $V$. uliginosum, while vegetative growth and total mass accumulation did not change. There were no changes detected in $V$. vitis-idaea [77]. A later study has confirmed this trend, indicating that horizontal growth of clonal arctic/alpine plants would not be strongly affected by a future warmer climate [78]. These findings suggest that the predicted future increase in air temperature will enhance the growth of dwarf shrubs most strongly in climatically harsh environments, but the growth of boreal species may also increase in climatically more benign areas. Under ambient conditions in the Pyrenees and in the Alps, V. uliginosum shows higher assimilation rates and degrees of stomatal opening, and uses recent assimilates as respiratory substrate more slowly than V. myrtillus. Carbon allocation dynamics in current-year shoots differ between the species, showing a progressive decrease in V. uliginosum shoots but a progressive increase in $V$. myrtillus shoots. Under drought conditions, a decrease in soil moisture causes a predawn osmotic potential $(\Psi \mathrm{s})$ of below $-1.2 \mathrm{MPa}$ in the leaves of both species, an effect close to wilting. However, the degree of stomatal opening (stomatal conductance) and the speed of transfer of newly assimilated $\mathrm{C}$ to belowground organs has been found to decrease only in V. uliginosum [79].

It is not easy to predict how Vaccinium species will react on climate change, and they often react differently. In a study, performed 1680 MASL in northern Japan the response to warming of circumpolar plants, growing at their southern distribution margin was undertaken in open-top-chambers (OTCs), the OTCs increased meantemperature $1.7^{\circ} \mathrm{C}$. Number of flowers and fruit yield was enhanced in V. uliginosum with the increase in temperature. In contrast, number of flowers decreased in the evergreens $V$. vitis-idaea and E. nigrum var. japonicum [80]. Wild berries, including V. uliginosum and V. vitis-idaea, in alpine fellfields in northern Japan and sub-arctic heathland in northern Sweden, have been found to show a positive correlation between flowering time and fruit set in Japan but not in Sweden. The different behavior is probably because a steep increase in air temperature from early to mid-summer occurred in the alpine fellfield [81].

\subsubsection{Development of wild berries under conditions created by climate change}

In Belarus, a climatic determination projection of the resources of major species of wild berries has suggested that $V$. oxycoccos L. and V. myrtillus L. may increase while $V$. vitis-idaea L. and V. uliginosum L. may decrease 
toward the end of the forecast period in the year 2050. The cover of all included species is projected to increase by $11 \%$ [82].

Vegetative and generative buds of wild berries burst early to cope with the short growing season, thus making the flowers more vulnerable to spring frost, as illustrated in transitional bogs in Lithuanian forests. Buds of $V$. uliginosum started to grow in early/mid May; flowering started in mid/late June, and the inflorescences contained one or two, or occasionally up to seven, flowers; fruit set was $0-52 \%$ and spring frost was the main danger; and the loss through pest and diseases was less than $1 \%$ [83]. Episodic frost during flowering is relatively frequent in alpine dwarf shrub habitats. Supercooling of reproductive shoots in alpine, woody plant species (including $E$. nigrum ssp. hermaphroditum) has been shown to be an effective mechanism that protects reproductive shoots from potential frost damage resulting from episodic freezing events [84].

Climate change may influence drought conditions. Although both V. myrtillus and V. uliginosum are largely tolerant to imposed drought, the results have indicated higher drought sensitivity of V. uliginosum than V. myrtillus, with potential implications for community composition and ecosystem cycling in the future climate [80]. In a study of an ecotone in the Pyrenean treeline, warming induced positive changes in the aboveground growth but not in the belowground growth of V. myrtillus, whereas V. uliginosum did not respond to warming. Warming did not induce shifts in the interaction between $V$. myrtillus and its neighboring species, in contrast with findings from previous studies, in which they were removed from their natural habitat, and species interactions changed at modified temperatures. These findings indicate that studies involving natural habitats are important in exploring the effects of environmental changes on plant-to-plant interactions [85].

Previous hypotheses suggest that Empetrum is an early flowering species, flowering directly after snowmelt and asynchronously along a snowmelt gradient. However, recent findings have shown that flowering of Empetrum does not relate to the time of snowmelt across all habitats but instead relates to temperature conditions during the last lag-phase between snowmelt and flowering. In addition, small-scale variation appears to matter less to flowering than inter annual differences in snowmelt timing. The topography within arctic-alpine landscapes is highly heterogeneous, thus resulting in diverse distribution patterns with different snowmelt timing in spring [86].

Climate change affects snow and ice cover, and cover becomes more variable in sub-arctic and arctic ecosystems. The snow cover may affect the physiological dehardening of $V$. vitis-idaea and V. uliginosum during the onset of spring. Individuals growing at less than $0.5 \mathrm{~m}$ snow cover are hardier and show moderately higher freezing tolerance than individuals covered with deep snow. Therefore, the freezing resistance of alpine plants with respect to snow depth can be a relevant driver of plant responses to climate change [87]. These events may become more frequent as ice encasement increases because of more unstable winters. The species V. uliginosum, $V$. vitis-idaea and E. nigrum have moderate to high tolerance to ice encasement. Even longer exposure under ice does not clearly increase damage [88]. In an Alpine dwarf-shrub community, freezing resistance has been found to be strongly species dependent and not to differ along the elevation or snowmelt gradient. Microclimate extrapolation suggests that potential lethal freezing events in May and June may have occurred for V. myrtillus, and that $V$. uliginosum has higher freezing tolerance [89]. Although warming is likely to decrease soil moisture, melt water from a deeper snow pack alleviates water stress in the early growing season. The study emphasizes the ecological importance of change in winter precipitation in the Arctic, which can interact with climate-warming effects. [90, 91].

In this perspective of climatic warming, the emission of biological volatile compounds (BVOC), such as sesquiterpene, are expected to increase. BVOC play an important role in the chemistry of the planetary boundary layer and contribute to the formation of ozone and to secondary organic aerosol formation through gas/particle partitioning of their tropospheric reaction products [92]. In a study in the Arctic, increased snow depth, warming and shading modified leaf anatomy, and the authors suggest links among leaf anatomy, $\mathrm{CO}_{2}$ exchange and BVOC emissions. The BVOC emissions were not affected by elevated temperature or by shading. This aerosol formation may be negative for human health in addition to having a direct effect on the Earth's climate through the scattering and absorption of solar radiation, and an indirect effect based on their role as cloud-condensation 
nuclei [93]. On the positive side, BVOC are assumed to benefit plants through positive and negative interactions in the environment, such as attracting pollinators and seed dispersers, and directly protecting plants from attacking herbivores [94]. Wild berries contribute to BVOC, and in a sub-arctic mountain birch floor, a high abundance of E. nigrum ssp. hermaphroditum has been found to increase sesquiterpene emissions. If the proportion of $V$. myrtillus and V. uliginosum vs. E. nigrum increases because of climate change, the emissions would be decreased because these species respond rapidly to the increased nutrient availability induced by a warmer climate [95].

\subsubsection{Effects of atmospheric $\mathrm{CO}_{2}$ and ultraviolet light.}

Elevated $\mathrm{CO}_{2}$ is a major issue concerning climate change, because it influences the temperature on Earth but also is a major factor in photosynthesis; although the latter is not a focus in the discussion regarding climate, it is key to plant growth. Elevated $\mathrm{CO}_{2}$ levels over 4 years have resulted in higher starch concentrations in V. myrtillus, $V$. uliginosum and E. nigrum ssp. hermaphroditum, but no change in $\mathrm{N}$ concentration or root dehydrogenase activity. In addition, root growth was not stimulated by higher levels, nor did altered root decomposition occur. The data indicate that fine root growth is stimulated by elevated $\mathrm{CO}_{2}$ to a lesser extent in systems with late successional elements than has been reported in ecosystems with a rapidly expanding plant community biomass [96]. A study in the Swiss Alps over 9 years in a treeline ecosystem has shown that a species-specific $\mathrm{CO}_{2}$ response occurred for abundant dwarf shrub species in the understory, wherein $V$. myrtillus showed a sustained shoot growth enhancement that was not apparent for V. uliginosum ssp. gaultherioides or E. nigrum ssp. hermaphroditum. These responses suggest a future shift in species composition with atmospheric change [97, 98].

The surface solar ultraviolet light B (UV-B) has increased during recent decades because of depletion of the ozone layer due to increased release of chlorofluorocarbons and other gaseous emissions [99]. Both UVB $(280-315 \mathrm{~nm})$ and UV-C (200-280 nm) have sufficient energy to damage different chemical bonds causing photochemical reactions, thus providing the main reason for the negative biological effects. The composition of $\mathrm{UV}$ radiation is modified because of its absorption by the atmosphere. Usually, UV-C radiation is fully absorbed, except in high mountain locations. UV-B radiation is absorbed only by the stratospheric ozone layer, and only a small fraction reaches the Earth's surface. A study over 7 years in northern Sweden has shown that enhanced UV-B negatively influences the growth, flowering and fruit yield and increases the leaf thickness of V. myrtillus, whereas V. uliginosum, V. vitis-idaea and E. nigrum ssp. hermaphroditum are generally tolerant. [100]. Another study in the same area has shown markedly different strategies among V. myrtillus, V. vitis-idaea and V. uliginosum in terms of localization and content of leaf phenolics and their response to UV-B enhancement, corresponding to a $15 \%$ depletion of stratospheric ozone for approximately 10 years before the start of the study. V. myrtillus exposed to elevated UV-B contained the highest concentration of methanol-extractable UV-B absorbing compounds, and the compounds were present throughout the leaf and were particularly concentrated in chlorophyll containing cells. In V. vitis-idaea, most phenolic compounds were cell wall-bound and concentrated in the walls of epidermis; this pool increased in response to UV-B enhancement. These two species might possibly represent extreme forms of two divergent strategies for UV-B screening, which may be related to leaf longevity. The response of $V$. uliginosum was intermediate between those of the other two species. One explanation for this finding is that the plant is deciduous, like V. myrtillus, but has leaves structurally similar to those of V. vitis-idaea [101]. Phenol oxidase is a bioindicator of the decomposition process. There was no enhanced UV-B treatment effect on phenol oxidase activity in litter from a field of E. nigrum ssp. hermaphroditum, V. vitis-idaea and V. myrtillus. However, in a controlled environment, significant species-to-species effects were evident, with increased phenol oxidase activity in V. vitis-idaea leachate [102].

\subsubsection{Effects of disturbance}

Disturbances may interact with climate and influence the development of wild berries. A study of effects in the Swedish alpine region of increasing temperatures on long term grazing, between 1995 and 2011 has shown that shrub expansion is occurring rapidly in the Scandes mountain range, both above and below the treeline. Tall, deciduous shrubs benefitted from grazing exclosure, both in terms of cover and height, which in turn lowered 
summer soil temperatures. However, the overriding vegetation shift across the sites resulted in a striking increase in evergreen dwarf shrubs (e.g., Empetrum), which was unaffected by grazing. This increase in evergreen dwarf shrubs, and more recalcitrant plant litter, may partially counteract some of the effects of an increase in deciduous tall shrubs. Herbivores' influence on shrub interactions may be highly important in shaping arctic shrub expansion and the associated ecosystem effects [103].

\section{The family Ericaceae $L$}

\subsection{The genus Vaccinium $L$.}

\subsubsection{General botanical characterization, origin and ethnobotany}

The genus Vaccinium consists of approximately 450 species, which are widely distributed in a range of areas throughout the world including northern Europe [104]. Several species have been exploited as wild berries or domesticated through clonal selection and breeding. Domestication has included lowbush- and highbushblueberry and cranberry, which are popular commercial berries. The European blueberry (V. myrtillus L.), and several other non-domesticated Vaccinium species, have a potential for domestication and/or better utilization. The most important species within Vaccinium L. that grow wild in northern and Central Europe are V. oxycoccos L. (Oxycoccus palustris Pers.), V. oxycoccos ssp. microcarpum Hook (Oxycoccus microcarpus Turcz. ex Rupr.), Vaccinium vitis-idaea L., V. myrtillus L. and V. uliginosum L. [13]. These species have complex polyploidy, thus making them difficult to classify taxonomically [105]. Several studies have found that berries of these species are good sources of polyphenols and exhibit a wide range of biological activities, including antioxidant, anticancer and antimicrobial activities [50-58].

At least four species within the Vaccinium genus have a potential for better exploitation and/or domestication: V. myrtillus L., V. vitis-idaea L., V. uliginosum L. and V. oxycoccos $L$.

\subsubsection{General conditions that influence plant development in wild Vaccinium}

The growth response as net primary production, of V. myrtillus and V. uliginosum in relation to soil nutrient availability is species dependent. The net primary production of $V$. uliginosum has been found not to vary among three subalpine communities in the northern Apennines (north Italy), whereas that of V. myrtillus has been found to peak in the most fertile habitat. The growth of V. myrtillus is P-limited, whereas that of V. uliginosum is not [106]. This result coincides with the finding that $V$. uliginosum is a character-species in oligotrophic communities, whereas V. myrtillus occurs on less oligotrophic sites of more composited peat [107].

Liming of a podzolic heather area in Norway altered the vegetation slowly but was pronounced at 6 years. It had a positive effect on V. uliginosum and V. vitis-idaea, but not on V. myrtillus. Adding P in addition to liming tended to favor all Vaccinium except $V$. myrtillus. Adding $\mathrm{Cu}$ in addition to liming promoted $V$. uliginosum and V. myrtillus [108].

\subsection{Species of Vaccinium $L$.}

\subsubsection{Vaccinium myrtillus $L$.}

\subsection{1.a. Botanical characterization, origin and ethnobotany}

V. myrtillus is typical and abundant in spruce-, pine- and birch dominated heath forests of medium fertility in the northern hemisphere [109] and is widely distributed across Europe and northern Asia (Fig. 1) [8, 110, 111]. The species is diploid, but other ploidy levels have been described [104, 105]. 
The highest $V$. myrtillus coverage in Finland has been found in mesic heath and fell forests [112]. The plant grows axils from underground rhizomes, which form bushes that can range from 10 to $60 \mathrm{~cm}$ high and have angular green stems whose older parts turn brown. The leaves are thin, light green, saw-tanned and deciduous. The mug shaped petals can vary from green-white to red, and the fruit has a sweet aromatic taste and is generally dark blue. Black-fruited types are common, and white-fruited types exist as well, but they are rare. The European blueberry is very common in most of Scandinavia and grows to an altitude of 1700 MASL in the municipalities Lom and Luster in southwest Norway [13, 113]. Vaccinium species are, in general, good seed dispersers and have high fecundity but usually lack developed seed banks; moreover, survivorship is similar on non-wood substrate and on decaying wood, but seedling growth is favored on the latter substrate [114].

In Norway, V. myrtillus seeds germinate when stored at $\pm 20^{\circ} \mathrm{C}$ for 5 months, or largely without pretreatment, such as fresh seeds, as observed in Italy [27, 115]. Seeds of $V$. myrtillus and V. vitis-idaea have been found to be conditionally dormant at maturity, when tested before and after cold stratification [116].

\subsection{1.b. Biotic, edaphic and nutritional conditions influencing V. myrtillus}

The yield of European blueberry (V. myrtillus L.) varies annually in Finland from 90 to 310 million kg [117]. Variation depends on forest management, among other factors; moreover, the yield in managed forests is higher than that in unmanaged stands, and the yield increases with stand age [117, 118]. These findings indicate that light conditions may influence the development of $V$. myrtillus stands. This observation is supported by the findings of Eckerter et al., who have revealed that the numbers of flowers, fruit and ovules; seed set; and other quality traits of $V$. myrtillus fruits are improved by higher light availability [119]. An investigation of V. myrtillus in pure and mixed stands with $V$. uliginosum and/or Rhododendron ferrugineum has shown that although $V$. myrtillus competes for nutrients with its neighbors, neither this competition nor the lower water use efficiency of $V$. myrtillus affects its aboveground performance. These results indicate that interaction with co-occurring shrubs does not have a major effect on V. myrtillus structure and function at the treeline and consequently should not be considered a key driver of the dynamics of this species in the encroachment of subalpine grasslands $[120,85]$. A Norwegian survey over 4 years has shown that location has a strong effect on canopy ground cover and the tiller height of European blueberry, and the highest increase of canopy cover was observed in spruce forests. Both cover and stem length tended to increase after NP fertilization at a relatively rich site compared with a poor site (probably because the rhizomes developed better in the rich site); however, fruit yield was highest without fertilization [27]. Pruning increased the thickness of the organic layer, but strong pruning of $V$. myrtillus has been shown to decrease the canopy cover and the height of tillers on a short-term basis $[27,121]$.

It is possible to grow $V$. myrtillus on cultivated land, as demonstrated in experiments mixing unfertilized peat into the silt loam soil before planting, followed by top dressing with peat in later years. The spatial growth of V. myrtillus seedlings has reacted positively to NP fertilization in trials. Additionally, mycorrhiza were established without seeding, and cuttings of fresh shoots rooted nearly $100 \%$, thus enabling reliable and inexpensive propagation [122-125].

\subsection{1.c. Variations in biological compounds in wild berries}

Flowering peaks of $V$. myrtillus synchronize over large areas, thus indicating that flowering is triggered by some large-scale environmental factors that act during key stages of the annual life cycle [126]. Factors linked to critical plant processes and events such as the timing of flower initiation, winter hardening, avoidance of frost injury during bloom and drought avoidance in summer are as follows: maximum temperature in June, mean temperature in August to September the year before fruiting, maximum snow depth in April, minimum temperature in May and hydrothermal ratio in June to July [127]. Regional environmental effects and annual climate have the greatest effect on the quality of V. myrtillus fruits compared with other wild berries [128]. In line 
with this finding, plant species originating from northern areas are better adapted to low temperatures and long days than clones originating from southern areas, and low temperatures increase the sugar content, acids and total phenols in V. myrtillus. [12]. In studies under a controlled environment using northern and southern clones, no differences in berry yields and quality have been detected between temperature treatments $\left(12\right.$ and $\left.18^{\circ} \mathrm{C}\right)$ the first year, but the second-year yield was highest at $18^{\circ} \mathrm{C}$. Berry ripening was faster in the most northern clones at $12^{\circ} \mathrm{C}$. Northern clones also showed higher content of total anthocyanins, all measured anthocyanin derivates, total phenolics, malic acid and sucrose. Metabolic profiling additionally revealed higher levels of flavanols, hydroxycinnamic acids, quinic acid and carbohydrates at the low temperature treatment [129].

The surrounding light conditions strongly affect the flavonoid composition of fruits. Higher solar radiation tends to increase flavonoid content in fruits, the spectral composition of light during berry development affects flavonoid composition of ripe fruits of V. myrtillus, and the compounds are influenced by regional origin [130-132]. A study in the Tuscan Apennines (Italy) using molecular clustering has shown no relationship with biochemical diversity. The remarkable variability of biochemical parameters investigated over 2 years was probably caused by variations in climatic conditions [128].

An examination of the effects of fertilization on fruit quality has shown that mineral NP fertilizers affected nutritional quality, whereas organic fertilization showed no effect over a 4-year period [133].

\subsection{1.c.2. Timing of harvest and influence of post-harvest on antioxidant activity}

Mid- and late- season harvesting, compared with early harvesting, have been found to enhance nutritional quality, owing to higher levels of phytochemicals beneficial to health and increased antioxidant activity [133]. Fruit potassium (K) was found to be especially high, but the amount was similar in open sites and in forest of the Italian Alps [134]. In fruit from commercial blueberry sites, no distinct differences have been found in the antioxidant activity of anthocyanin extracts among fresh, dried, and frozen fruits [135]. This effect might also be similar for V. myrtillus fruit (author comment).

\subsubsection{V. vitis-idaea $L$.}

\subsection{2.a. Botanical characterization, origin and ethnobotany}

$V$. vitis-idaea is a perennial evergreen wild berry distributed in arctic, alpine and boreal areas. The plant height is between 15 and $30 \mathrm{~cm}$, and the ripe fruit is red and $6-10 \mathrm{~mm}$ in diameter. V. vitis-idaea is diploid $(2 \mathrm{n}=24)$ and reproduces either vegetatively through rhizomes or sexually through seeds. The plants are extremely frost tolerant and can tolerate temperatures $-40^{\circ} \mathrm{C}$ or lower. Plants grow poorly in areas with warm summers, and the distribution is restricted to northern and mountainous areas in Europe and North Russia; south to the Pyrenees, northern Italy, the Balkans and Caucasus, northeastern Canada and Alaska (Fig. 2) [8, 136]. It thrives in acidic soils $(\mathrm{pH} 3.5-5)$ and is found in a range of habitats, from lowland to mountain areas.

$V$. vitis-idaea has a long history of harvesting from native stands, and the fruit are traditionally used in jams, jellies and juices $[1,2]$.

\subsection{2.b. Biotic, edaphic and nutritional conditions influencing V. vitis-idaea}

Reactivation of inactive lateral meristems has been found to increase when $\mathrm{N}$ is added for shoot growth by annual $\mathrm{N}$ fertilization in 2 years at levels of 0.5 or $10 \mathrm{~g} \mathrm{~m}^{-2}$ in three equal doses in early June, mid-July and late August [137]. A Norwegian survey over 4 years has shown that the ground cover of $V$. vitis-idaea decreased from the beginning to the end of the survey period, and the plants adapted better than V. myrtillus to poor sites. Moreover, fertilization generally decreased the growth of $V$. vitis-idaea, thus suggesting that the species has a lower nutrient demand than V. myrtillus. [121]. In a sandy soil, mulching using peat, pinewood, sawdust, chopped straw or sand has been found to increase the number of rhizomes, phytomass, berry size and yield of $V$. vitis-idaea 
[138]. In addition, the flowers suffered less from frost. Reactions of biotic and edaphic factors among populations may vary, because $V$. vitis-idaea populations are variable in nearly all important horticultural traits $[10,11]$.

\subsection{2.c. Variations in health-affecting biological compounds, due to climate, latitude, mineral nutrition, timing of harvest and post-harvest influences}

Like other Vaccinium species, V. vitis-idaea has a wide spectrum of beneficial biological properties, and it may be effective in lowering human blood pressure, because juice lowers blood pressure in spontaneously hypertensive rats. [139]. It has also been found to prevent urinary tract infection [140]. Anthocyanins from V. vitis-idaea have been found to decrease radiation-induced damage [141].

\subsection{2.c.1. Climatic effects on growth and post-harvest qualities}

An ecological study has revealed that snow cover protects $V$. vitis-idaea plants from adverse winter conditions and the plant retains its photosynthetic capacity under snow cover. A down-regulation of photosynthesis occurs with increased snow pressure. More irregular snow cover in the future may affect the carbon balance of plants [142].

Fresh, good colored, visually mature and healthy berries can be stored at low temperatures $\left(1-2^{\circ} \mathrm{C}\right)$ for several weeks. Even after 6 weeks of storage in unperforated polyethylene bags, the number of spoiled berries has been found to remain below $10 \%$. The bags improve preservation of $V$. vitis-idaea, but compositional variation might affect fruit quality during storage, especially among wild clones. The reason for the good storage ability probably was high levels of carbon dioxide and low levels of oxygen, and a lack of ethylene production in the unperforated bags. Another reason for the slower spoilage of the berries may have been their naturally high level of benzoic acid [143-146].

\subsubsection{V. uliginosum $L$.}

\subsection{3.a. Botanical characterization, origin and ethnobotany}

The species has a circumpolar distribution; it is widely distributed in North America, Europe and Asia (Fig. 3) and has been a part of the diets of local populations. Seeds have been found at Svalbard, but they did not germinate $[1,2,8,13,147,148]$.

The species grows on acidic, peaty soil and is found in bogs, muskegs and open alpine and arctic tundras. $V$. uliginosum occurs as solitary shrubs or large clones and is spread by layering of aboveground shoots buried in organic matter [149].

In an Alaskan black spruce forest, new growth of $V$. uliginosum comprises more than $50 \%$ of the aboveground biomass, because the plants have a small support structure and rapid turnover of biomass and nutrients relative to that of the trees [150]. Separating layered shoots of V. uliginosum from the parent plant, to mimic forest fire injury, has been found to initiate some damage 8 weeks later; however, 1 year later, the treatment increased the weight ratio of fine-roots/leaves and the surface area ratio [151], thus demonstrating good recovery. Plant regeneration and a rapid propagation-system of $V$. uliginosum has been successfully established by in vitro culture [152].

\subsection{3.b. Biotic, edaphic and nutritional conditions influencing V. uliginosum}

Forests are important resources for timber and firewood, compared with early harvest and other wood-based products, as well as other plants that grow on the forest floor, such as wild berries. How forests are cultivated may substantially influence wild berries; for example, clearing has a major influence. In a principal component analysis, the three principal components 1) available $\mathrm{N}, \mathrm{K}, \mathrm{P}$, moisture and organic content in soil, 2) medium sunlight, high sunlight and low sunlight, and 3) soil moisture and $\mathrm{pH}$, have been found to contribute approximately 
$80 \%$. Available N, K, P, moisture and organic content in soil have the highest positive effect on fruit yield. The strong effect of sunlight on fruit yield was greater than that of medium sunlight, and the third main factor influencing fruit yield was soil acidity [153]. Because of the increased acidity of rivers and lakes in recent decades, which is not beneficial for fauna, liming has decreased the problem. However, increasing the $\mathrm{pH}$ of the soil may not benefit wild berries. Liming $\left(2,4\right.$ and $\left.6 \mathrm{t} \mathrm{ha}^{-1}\right)$ and fertilizing $\left(600 \mathrm{~kg} \mathrm{NPK} \mathrm{ha}^{-1}\right)$ of $V$. uliginosum stands growing on a soligenous mire in southeast Norway in 1955 decreased the plant cover [154], an effect probably caused by the increasing $\mathrm{pH}$. A recent study has demonstrated that the amounts of phosphorous $(\mathrm{P})$, iron $(\mathrm{Fe})$, magnesium $(\mathrm{Mg})$ and copper $(\mathrm{Cu})$ in leaves of $V$. uliginosum decrease with increasing pH [155]. In addition, soil $\mathrm{pH}$ has a large effect on element content in roots. The number of shoots of $\mathrm{V}$. uliginosum in a bog site in Alaska increased with $\mathrm{N}$ fertilization when $\mathrm{N}$ was applied as urea annually for 2 years at 0,5 or $10 \mathrm{~g} \mathrm{~m}^{-2}$, in three equal doses in early June, mid-July and late August. Additionally, shoot length increased, and larger shoots produced more daughter shoots than small ones [137]. Other positive effects of fertilizers (NPK $50 \mathrm{~g} \mathrm{~m}^{-2}$ ) on the growth of $V$. uliginosum in a 5 year period on a ski-slope were greater shoot length, number of rammets and leaf size, as compared with those of the untreated control [156]. In addition, bud break was earlier, and the bud development in autumn was incomplete; both events increased the danger of frost injury. Other results indicated that alpine graminoids received the greatest advantage from elevated nutrients, because $V$. uliginosum had a high nutrient storage capacity and access to organic forms of $\mathrm{N}$ through its mycorrhizal association [157, 158], owing to the high nutrient storage capacity of $V$. uliginosum and the mycorrhizal association providing access to organic forms of $\mathrm{N}$. In sandy soil, mulching increased the number of shoots, leaf size, berry size and yield [138].

Pollination is another factor important for fruit yield of $V$. uliginosum. Habitat fragmentation might not immediately threaten the pollination of $V$. uliginosum, but a declining population may have negative effects for its pollinators [159].

Natural protection against pathogens is important for the growth and development of $V$. uliginosum plants. A strain of endophytic bacteria (Serratia marcescens) isolated from the roots of $V$. uliginosum has been found to inhibit growth of the causal agents of blueberry leaf spot and that of ten more plant fungal pathogens [160, 161]. Higher winter temperatures might increase the mortality of $V$. uliginosum, owing to fungal attack on ecotypes not adapted to mild winters [162]. The stenotopic Lepidoptera that feed on V. uliginosum are extensively parasitized by the families Braconidae and Ichneumonidae [163], thus suggesting a potential for biological pest control.

\subsection{3.c. Variations in health-associated biological compounds in V. uliginosum, due to climate, mineral nutrition and ripening stage}

\subsection{3.c.1. Effects on human health}

Berries and/or extracts improve atopic dermatitis disease in mice $[164,87]$ and have anticancer effects on human colon or colorectal cancers [165]. Anthocyanin-rich extracts from V. uliginosum showed more comprehensive and beneficial effects than metformin in protecting $\beta$-cells against glucolipotoxicity [166].

\subsection{3.c.2. Content of biological compounds}

V. uliginosum is recognized as a valuable food and medical plant [167]. It has potent antioxidant activity, and flavonoids have been isolated as the main active component [168]. The major soluble sugar identified in the fruit is fructose, followed by glucose, and the main organic acid is citric acid followed by malic acid. Eleven phenolic acids and 17 anthocyanin 3-glucosides have been identified and quantified. Caffeic acid in the free and glycoside forms and syringic acid in the ester form are the major phenolic acids, and the major individual anthocyanin is malvidin 3-glucoside [169]. Two new ortho-benzyloxyphenyl acetic acid derivates, vacciuligins A (1) and B (2), along with five known compounds, quercetin $3-\mathrm{O}-\alpha$-arabinopyranoside (3), syringetin 3-O- $\beta$-glucopyranoside 
(4), syringetin 3-O- $\beta$-galactopyranoside (5), protocatechuic acid (6) and syringic acid, have been isolated from V. uliginosum. In addition, 12 different anthocyanins have been identified [170].

In the high mountain pastures in northeast Anatolia, Turkey, the highest phenolics and anthocyanin content are from the anthocyanin fraction in conjunction with the highest antioxidant capacity, followed by the polyphenolic and aqueous fractions [169].

During ripening, levels of anthocyanins increase, while proteins, amino acids and leucoanthocyanins decrease [138]. Application of phosphate-potassium and NPK fertilizer equally promotes the activation of useful substances in V. uliginosum berries [171].

\subsection{3.d. Climatic effects on plant development}

A study of wetland habitats, bogs and fens (including V. uliginosum) in southern Germany has indicated that these habitats in the past were more frequently present and were in better condition than they are today, and they have now become rare habitat types [172]. V. uliginosum has been predicted to be more susceptible to freeze-thaw-induced disturbance than evergreen plants such as E. nigrum ssp. hermaphroditum and V. vitisidaea. These results may predict the future composition and plant community structure of arctic species [173]. Warming in the Changbai mountain tundra, China, increased the soil $\mathrm{N}$ and P levels by $5.88 \%$ and $4.83 \%$, respectively, but decreased the $\mathrm{C}$ content by $13.19 \%$. The $\mathrm{P}$ content in leaves of $\mathrm{V}$. uliginosum in both OTCs and in controls increased with warming by $10.34 \%$ and $12.87 \%$, respectively, thus indicating that warming would decrease the P limitation to plant growth [174]. A study on the recovery of tundra vegetation on the depth of permafrost thaw on the Seward peninsula in Alaska has revealed that the cover of evergreen shrubs, bryophytes and lichens remained drastically decreased 5 years after a fire and had not yet recovered even 10 years after the fire. However, graminoids and V. uliginosum increased. The deeper thaw after the fire and the following favorable growing conditions did not last long [175].

\subsubsection{V. oxycoccos $L$.}

\subsection{4.a. Botanical characterization, origin and ethnobotany}

V. oxycoccos is a species of flowering plant in the heath family that is widespread throughout the cool temperate northern hemisphere (Fig. 4) $[8,13,176]$. The species is a small, prostrate shrub with vine-like stems, often a meter long; it develops roots at the nodes and mainly reproduces vegetatively. The leaves are leathery and lance-shaped, $8-10 \mathrm{~mm}$ long and $1-2.5 \mathrm{~mm}$ wide. Flowers, most often singular, arise on nodding stalks a few centimeters long. The corolla is white or pink and flexed backward away from the center of the flower. The fruit is red, with a juicy berry, which has spots when developing. It measures $8-12 \mathrm{~mm}$ long. The plant has underground perennating structures well below the surface, which form associations with mycorrhizae. [13, 176]. The species has been a part of the diet of local populations in areas where it grows naturally, similarly to other wild berries $[1,2]$.

\subsection{4.b. Biotic, edaphic, and nutritional conditions influencing V. oxycoccos}

V. oxycoccos is an indicator of moist to wet soils, low $\mathrm{N}$, a high water table and coniferous swamps. The plant often grows on hummocks of Sphagnum mosses [13, 176]. The positive influence of mycorrhiza has been demonstrated by growing the cranberry $V$. macrocarpon in containers in a nursery. 'Pilgrim' showed a greater weight of plant shoots as well as higher content of $\mathrm{N}, \mathrm{P}, \mathrm{K}$, calcium $(\mathrm{Ca})$ and $\mathrm{Mg}$ when supplied with a mycorrhizal inoculation. Slow-release fertilizers had a positive effect on plant weight and their chemical composition, whereas plants fertigated developed a lower mass of shoots and contained less $\mathrm{N}, \mathrm{P}, \mathrm{K}, \mathrm{Ca}$ and $\mathrm{Mg}$ [177]. $\mathrm{N}$ and $\mathrm{K}$ fertilization of cranberry at $10 \mathrm{~kg} \mathrm{ha}^{-1}$ did not affect the course of phenophases and plant 
morphology, but had more favorable effects on yield than combinations with higher amounts of K, particularly for 'Pilgrim' and 'Steven' [178].

The soil in bogs is acidic and low in nutrients, but the plant's mycorrhiza help to obtain nutrients in this situation. Results from Latvia comparing the American cranberry (V. macrocarpon Ait.) with wild cranberry ( $V$. oxycoccos L.) suggest that only $50 \%$ of cranberry producing plantings in Latvia were optimally provided with all nutrients. Insufficient levels of N, phosphorus, $\mathrm{S}, \mathrm{Cu}$ and molybdenum (Mo), and high concentrations of $\mathrm{Mn}$ are major problems. High bogs are characterized as particularly nutrient poor environments, but wild cranberries show a high efficiency of obtaining Fe, $\mathrm{Zn}$ and Mn [179].

\subsection{4.c. Variations in biological compounds in V. oxycoccos}

\subsection{4.c.1. Effects of biological compounds on human health}

Cranberry contains high quantities of phenolic compounds, and extracts can prevent atherosclerosis, restore blood vessel elasticity, eliminate eye fatigue and improve eyesight; moreover, there is considerable evidence that they can prevent and treat cancer and strengthen the function of the heart. V. oxycoccos, like V. vitis-idaea, also is effective in the treatment of urinary tract infections [180-183].

A Latvian study has revealed significant differences in the mineral composition of $V$. oxycoccos and V. macrocarpon. Cultivated cranberry fruits have a higher content of $\mathrm{P}$ and $\mathrm{Fe}$, whereas $V$. oxycoccos shows higher levels of $\mathrm{Ca}, \mathrm{Mg}, \mathrm{Mn}, \mathrm{Zn}, \mathrm{Cu}$ and boron (B). Fruit of both species is a valuable source of microelements in the human diet. Because $V$. oxycoccos has an especially high concentration of $\mathrm{Mn}, 100 \mathrm{~g}$ of fresh berries could supply more than the daily requirement for adults [184].

\subsection{4.c.2. Content of biological compounds}

V. oxycoccos is a good source of vitamins. The content of vitamin C is very similar within cranberry cultivars, and 'Early black' has the lowest content, comparable to that of wild cranberries [181, 184]. The vitamin content of B1 and B2 in wild and cultivated cranberries is similar, and the highest vitamin E content is found in wild cranberry and in 'Ben Lear' and 'Pilgrim'. The highest content of essential amino acids is in wild berries, 'Bergman', 'Pilgrim' and 'Early Black' [185].

The highest content of benzoic acid is in 'Early Black', at levels 56\% higher than those in $V$. oxycoccos and 'Steven'. The highest salicylic acid content in berries is in 'Pilgrim', at levels15\% higher than those in $V$. oxycoccos and $60 \%$ higher than those in 'Bergman'. Polyphenols are highest in 'Pilgrim', Early Black' and 'Steven', and lowest in 'Bergman, whereas $V$. oxycoccos has intermediate levels. The color of $V$. oxycoccos is darker than that of $V$. macrocarpon. [186], and proanthocyanidins constitute approximately $50 \%$ of polyphenols in fruit extract [187].

\subsection{4.c.3. Effect of post-harvest on fruit quality}

Preserving fruits by drying influences the content of organic acids. Freeze-dried fruit contains distinctly more organic acids but less flavonoids than fruit dried at $35-45^{\circ} \mathrm{C}$. The largest relative differences have been observed in ascorbic acid, whose content in thermal dried fruit is $42 \%$ lower than that in freeze-dried fruit [188].

\subsection{4.d. Climatic effects on growth}

Several findings indicate that cranberry responds negatively to warming [189, 190]. Mycorrhizal cranberry plants have higher tolerance to drought than non-mycorrhizal plants, as shown by enhanced production of uprights, higher water potential in shoots and higher rates of gas exchange [191]. 


\section{The family Empetraceae L.}

\subsection{The genus Empetrum L.}

\subsubsection{Empetrum nigrum L. including ssp. nigrum, ssp. hermaphroditum and ssp. japonicum}

\subsection{1.a. Botanical characterization, origin and ethnobotany}

Empetrum nigrum L. is a boreal species in the northern hemisphere (Fig. 5), including both arctic and alpine environments as well as temperate and sub-arctic climates. It is an evergreen dwarf shrub with a narrow leaf and curved edge. The flowers are dark red. The pistils reach out of the flower, and the species is wind pollinated. The fruit is a black and juicy stone fruit with several seeds. Empetrum nigrum has several subspecies, including ssp. nigrum, hermaphroditum and japonicum. Subspecies nigrum is $5-30 \mathrm{~cm}$ high and has long, creeping shoots that root, and the flowers are dioecious. The subspecies hermaphroditum is slightly shorter and has creeping shoots that do not root, and the flowers are monoecious. The species grow in nutrient-poor soils [8, 13, 192]. In a study on a sand dune system in sub-arctic Québec, Canada, the population of E. nigrum ssp. hermaphroditum continued to experience abundant recruitment, fast growth and low mortality, thus resulting in a $40 \%$ increase in the population size and a large increase in cover. The ability of Empetrum to successfully establish seeds might have been enhanced by the regional warming observed since the 1990s. This seems to be part of a dual strategy allowing Empetrum to fill gaps through seed dispersal, while continuing to spread efficiently on the dune system via clonal growth [193].

\subsection{1.b. Biotic, edaphic and nutritional factors influencing E. nigrum}

Empetrum nigrum ssp. nigrum grows in dry heather, peat forests and in bogs. The ssp. hermaphroditum grows in heather forests and heathers, and on tufts in bogs, on ridges at hillsides and in the mountains [13]. In an ongoing long-term fertilization experiment in northern Sweden initiated in 1989, fertilization caused replacement of the dominant E. nigrum with Deschampsia flexuosa [39]. After fertilization of understory plants of a boreal forest, $\left(0.5\right.$ to $\left.17.5 \mathrm{~g} \mathrm{~N} \mathrm{~m}^{-2}\right)$ in Yukon, North America, E. nigrum generally had a positive effect with low $\mathrm{N}$ levels but reacted negatively to high $\mathrm{N}$ levels [194]. Empetrum often grow together with Pleurocarpous feather mosses. These mosses host di-nitrogen $\left(\mathrm{N}_{2}\right)$ fixing cyanobacteria, and the associated $\mathrm{N}_{2}$-fixation can be important to maintain a long-term $\mathrm{N}$ balance and should be accounted for when modeling $\mathrm{N}$ balance in $\mathrm{N}$-limited managed boreal forests [195].

Empetrum have allelopathic effects on both Pinus sylvestris and its ectomycorrhizal symbionts. In the harsh physical conditions of a dune shore, Empetrum facilitated pine seedling (P. sylvestris) establishment in the early and mid-stages of succession by providing mechanical and physical shelter. However, in late succession negative interactions (competition and allelopathy) between the shrub and the pine are dominating [196]. However, Empetrum has negative effects on the seeds and seedlings of Pinus sylvestris and Populus tremula, and more so for E. nigrum ssp. hermaphroditum than for E. nigrum ssp. nigrum, owing to the different chemical profiles of the two species. Interestingly, addition of activated carbon partially reversed this effect. [197]. Moreover, humus of the dominant $E$. nigrum ssp. hermaphroditum releases allelopathic substances that accumulate in soil over time, thus making the humus infertile for seedlings of local herbaceous plants. Herbivore defecation and wildfires are likely to alleviate the effects of these allelopathic substances. Simulating such events on Empetrum humus causes three to five-fold increases in growth of Avenella flexuosa and Solidago virgaurea, respectively. Changes in soil chemistry caused by the disturbance (i.e., increased $\mathrm{pH}$ and nutrient availability) interfere with allelopathic effects and improve conditions for growth, at the expense of Empetrum [198].

Mycorrhiza are a dominant factor supporting the roots with necessary plant building elements from the soil. Dark septate endophytes (DSE) have been shown to be important when establishing seedlings of $V$. myrtillus on cultivated land in Norway $[122,125]$. The host effect on ericoid mycorrhizal (ErM) fungal communities 


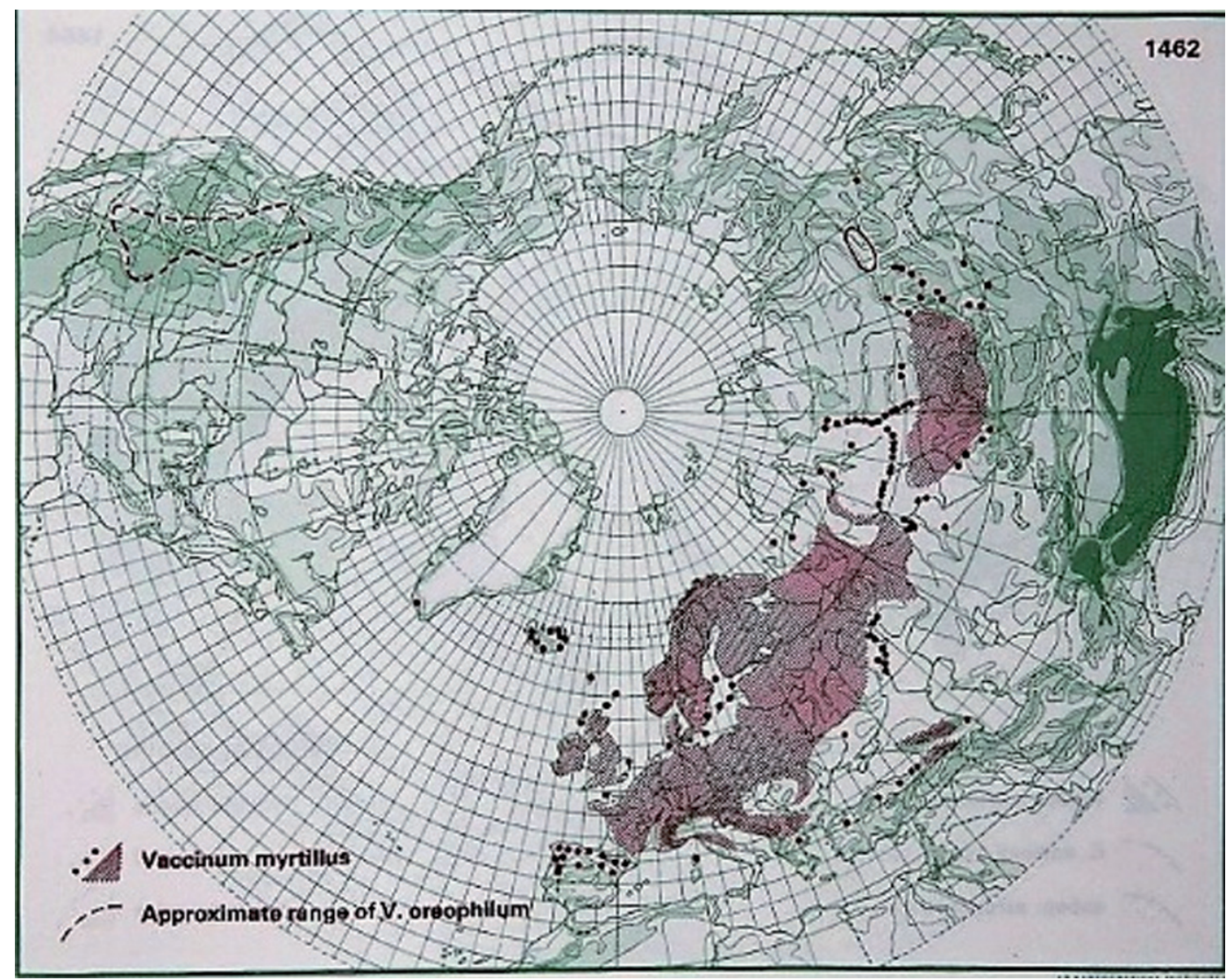

Fig. 1. Distribution of V. myrtillus L. in the northern hemisphere (Hultén and Fries 1986), with the kind permission of Per Koeltz.

is minor, and the distributions of host and fungal communities may be assessed on the basis of microhabitat conditions [199]. Broader insight into how mycorrhiza influence plant growth has been achieved by studying how root fungal colonization of Deschampsia flexuosa (wavy hair-grass) by arbuscular mycorrhizal (AM) fungi and DSE changes along a postglacial primary successional land uplift gradient, or after removal of the dominant neighbor E. nigrum spp. hermaphroditum. A shift appeared from an AM-dominated to a DSE-dominated root fungal community after removal of the neighbor. This effect may have been related to different nutritional benefits (induced by climate warming) gained through these root fungal groups [200].

\subsection{1.c. Variations in health-affecting biological compounds of Empetrum, due to latitude, mineral nutrition, ripening stage and post-harvest influences}

\subsection{1.c.1. Effects of biological compounds on human health}

E. nigrum is associated with a decrease in the risk of developing chronic diseases, because of its strong antioxidant activity and high content of biologically active substances, especially flavonoids, as generally found in wild and cultivated berries [40]. It is also rich in different nutrients, some of which contribute to orosensory properties. Empetrum extract has been demonstrated to protect cells against $\mathrm{H}_{2} \mathrm{O}_{2}$-induced cell damage via antioxidant properties by scavenging reactive oxygen species and by enhancing antioxidant enzyme activities, 


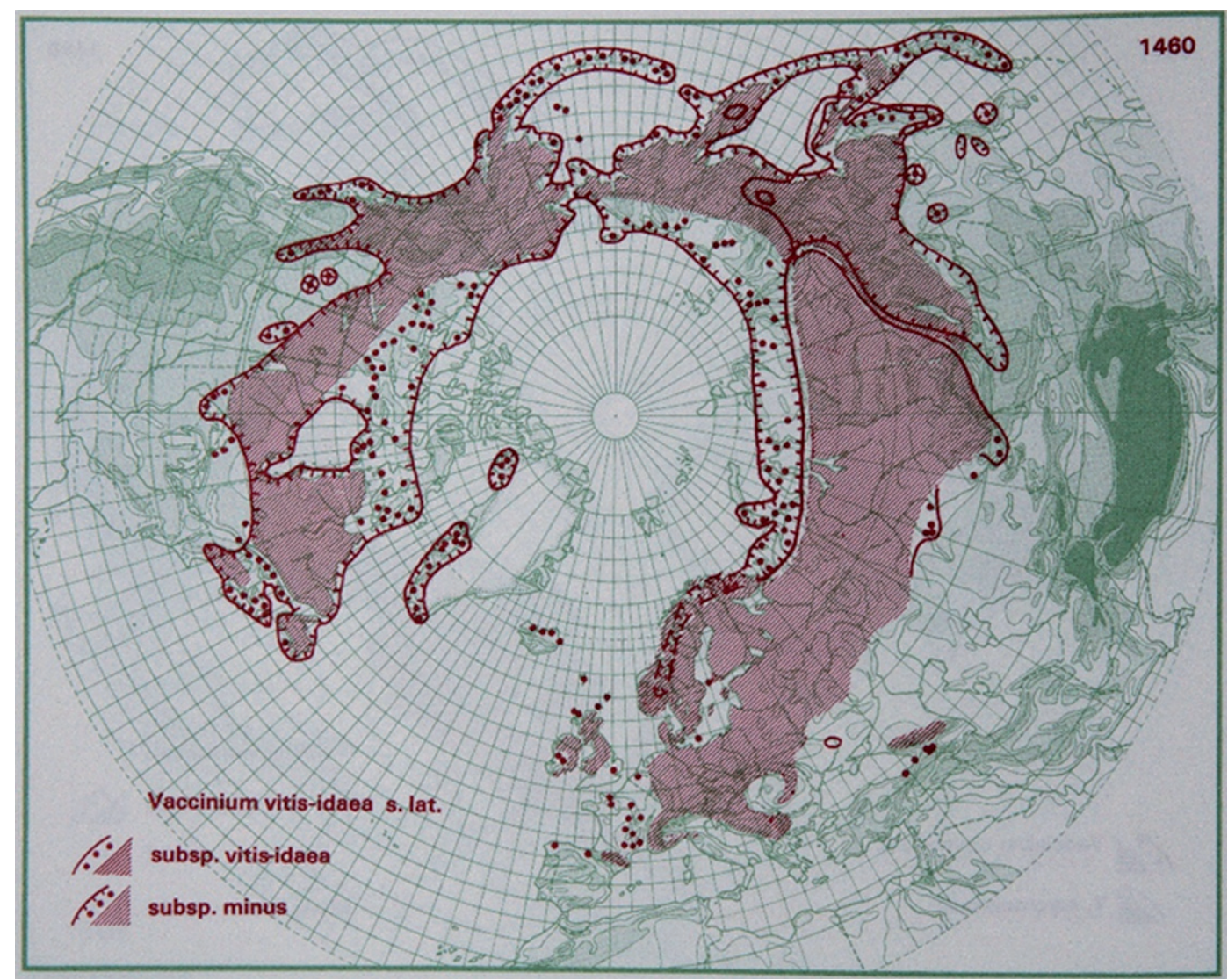

Fig. 2. Distribution of V. vitis-idaea L. in the northern hemisphere (Hultén and Fries 1986), with the kind permission of Per Koeltz.

and it displays anti-inflammatory and anticancer activity, and has a positive effect on lipid metabolism [201, 202]. In addition, Empetrum nigrum ssp. japonicum might have potential value to prevent and treat angiogenesisdependent human diseases [203]. However, some phenols may be injurious to the environment. Release of the dihydrostilbene batatsin-III from leaves and litter by rain and snowmelt may impose a lethal effect on the aquatic fauna in small streams [204].

\subsection{1.c.2. Content of biological compounds in Empetrum}

Eight flavonol glycosides and two flavonol aglycones particularly contribute to bitterness and astringency [205]. A study of the anthocyanin composition and antioxidant activity of Empetrum nigrum has identified 13 anthocyanins. The major anthocyanins are cyanidin-3-galactoside and delphinidin-3-galactoside, at 8.04 and $8.62 \mathrm{mg} \mathrm{g}^{-1}$ extract, respectively. The HPLC profile of the extract was comparable to that of V. myrtillus L. and cultivated blueberry V. corymbosum. The total content of anthocyanins in E. nigrum was $41.8 \mathrm{mg} \mathrm{g}^{-1}$ extract, a level higher than those in the other nine major berry species $\left(2.5-38.8 \mathrm{mg} \mathrm{g}^{-1}\right.$ extract), and the Empetrum extract exerted the strongest antioxidant activity [206]. The phytochemical content of these fruit consisted mainly of flavonoids. Fifteen soluble phenolic compounds were identified as anthocyanidins, and 14 were identified as flavonols. Proanthocyanidins were the second most abundant component and comprised most of the other half of the phenolic content of fruit [207]. 


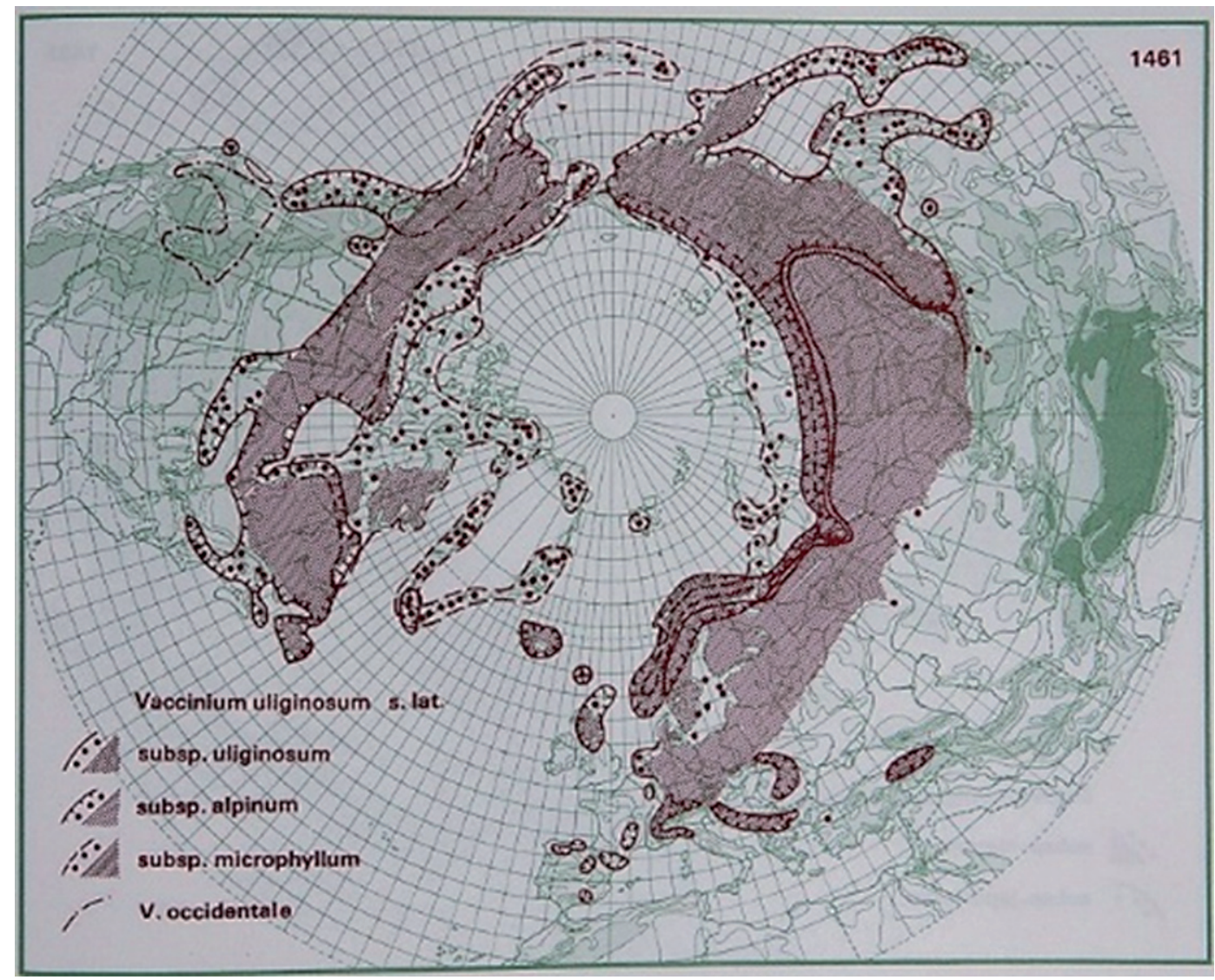

Fig. 3. Distribution of V. uliginosum L. in the northern hemisphere (Hultén and Fries 1986), with the kind permission of Per Koeltz.

\subsection{1.c.3. Influence on post-harvest}

Most of the sugars were in the juice, whereas the majority of phenolic compounds, the anthocyanins, were located in the press residue. Ethanol extracts of the press residue contained nearly all the phenolic compounds, which were the most bitter and astringent of the fractions [205]. Drying prolonged the storage of fruits of E. nigrum grown 1050 MASL at Harghita in Romania. In addition, the total polyphenol content was 1.6 times higher in extracts of dried fruit than fresh fruit. The flavonoid content (catechin equivalent; CE) in fresh and dried fruit was 2.26 and $3.94 \mathrm{mg} \mathrm{CE} \mathrm{g}^{-1} \mathrm{DW}$, respectively. These results showed that the drying process increased the levels of both polyphenols and flavonoids [192].

\subsection{1.d. Effects on growth of climate and disturbance}

\subsection{1.d.1. Effects of climate}

Biotic interactions play an important role in arctic-alpine vegetation. A study including E. nigrum over 15 years in Torneträsk, north Sweden has concluded that a long time series is essential to identify key biotic interactions in ecosystems, because their presence is influenced by climatic conditions, and manipulative treatments are needed to obtain the mechanistic understanding required for robust predictions of future ecosystem changes 


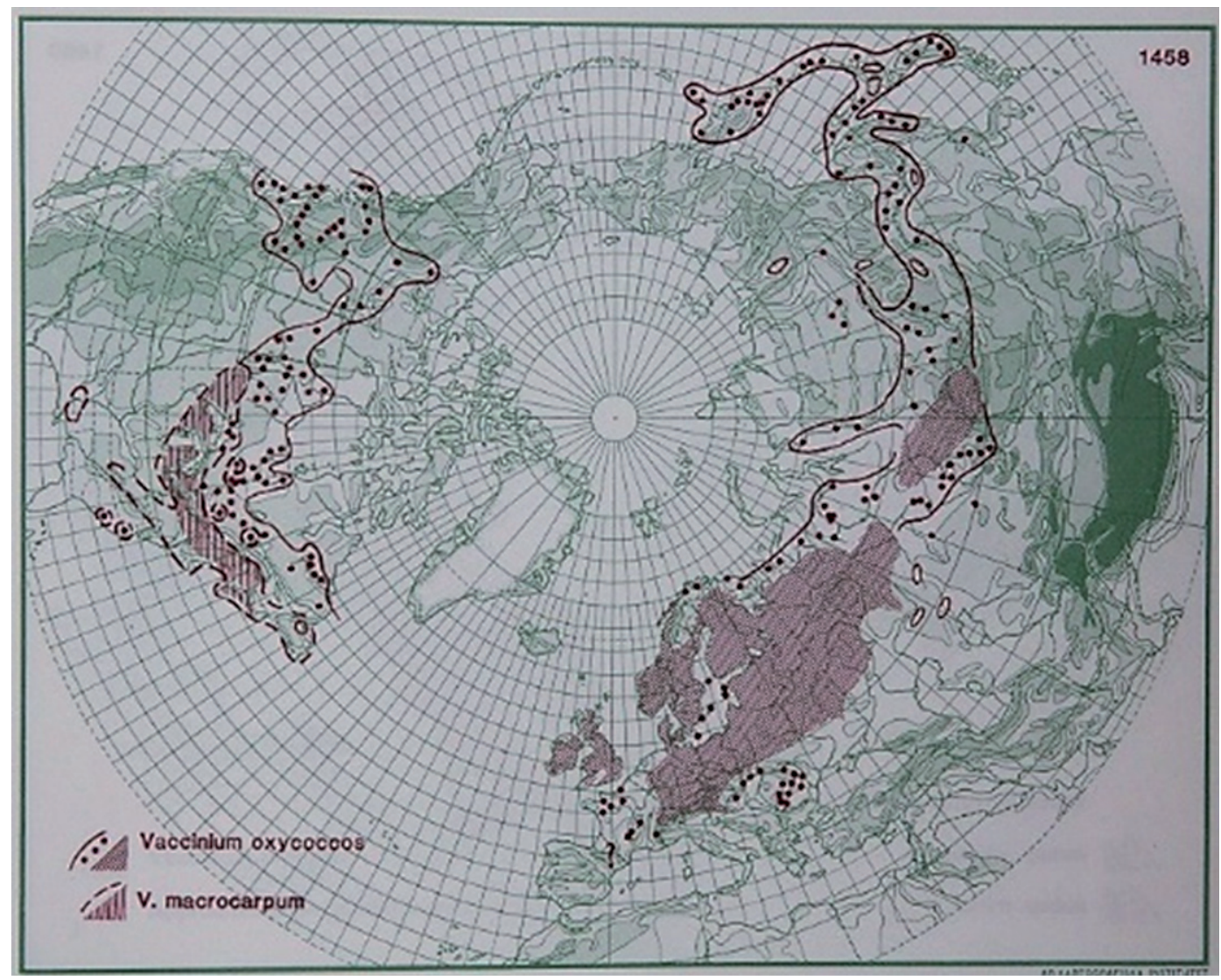

Fig. 4. Distribution of V. oxycoccos L. and ssp. macrocarpum in the northern hemisphere (Hultén and Fries 1986), with the kind permission of Per Koeltz.

and their feedback effects [208]. Another, more limited, study in north Finland of 17 arctic-alpine species as a function of Empetrum nigrum ssp. hermaphroditum has shown that the outcome of biotic interactions is frequently dependent on two abiotic variables, reproduction effort and cover. Studies based on only one environmental factor may cause misleading interpretations of the nature of biotic interactions in plant communities, where there are multiple independent variables underlying the habitat severity gradient [209].

Warming has a strong effect on Empetrum, as shown by the growth responses of Empetrum nigrum ssp. hermaphroditum to environmental manipulations in the Finnish sub-arctic: shoot growth increased in the second and third seasons when temperature increased $\left(+2^{\circ} \mathrm{C}\right.$ in a greenhouse). Elevated temperature also accelerated the vegetative bud break and shifted the peak shoot growth to an earlier time. The growth tended to decrease when plants were watered above the level of natural (50-70\% more in the last 2 of 3 years) summer precipitation [210]. In contrast, a study including Sardinia in the south to Denmark in the north over 7 years has shown that Empetrum nigrum tends to grow less under a $1{ }^{\circ} \mathrm{C}$ warming treatment. The finding that one of the studied shrub-lands presented negative aboveground net primary productivity as a response to the 2003 heat wave also challenged the hypothesis that future climate warming will lead to an enhancement of plant growth and carbon sequestration in temperate ecosystems [211]. 

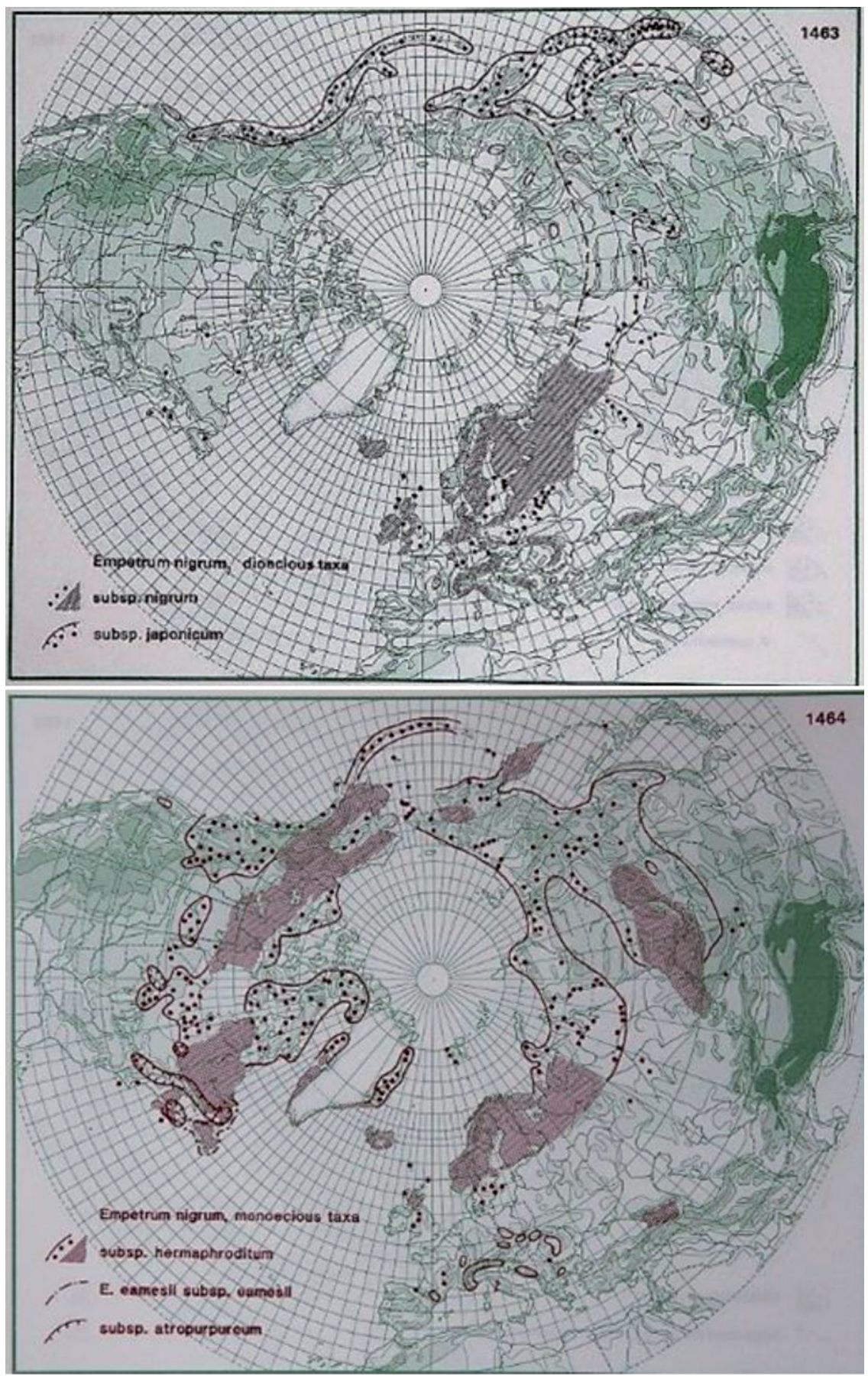

Fig. 5. Distribution of E. nigrum L., E. nigrum ssp. nigrum and E. nigrum ssp. japonicum (upper photo) and E. nigrum ssp. hermaphroditum (lower photo) in the northern hemisphere (Hultén and Fries 1986), with the kind permission of Per Koeltz. 
Seeds from E. nigrum show increased germination as a response to warmer summers, whereas increased winter temperature has no effect on germination. Additionally, longer summers might favor slow-germinating species [162]. Marked effects of year have been observed in Yukon, North America (spring 2004 and 2005) for some plant growth metrics and in berry production, thus emphasizing the role of climate but also providing clear evidence that individual species such as E. nigrum, trade off somatic growth for reproduction [194].

The clonality of E. nigrum ssp. hermaphroditum differs between habitats in Norway and Sweden, with an increase in clonal diversity with decreasing snow depth. The small-scale spatial genetic structure increases with decreasing clonal diversity and increasing clone size. These findings demonstrate that snow cover and associated habitat conditions play an important role in the mode of propagation [212]. Simulating global warming has suggested a negative response of Empetrum to warming in the 'south' (the Netherlands) and a positive response at the northern range margin (tundra of Svalbard). However, warming in the south was in fact beneficial for the growth parameters and fruit size of Empetrum when the growing season was extended by 75 days. In the north, Empetrum responded as expected, with increased shoot and biomass growth, enhanced fruit development and ripening to warming. The direct ecological responses found at the northern range of Empetrum are in line with the increased occurrences of this species on Svalbard [213]. A parallel effect was observed at three sites in the forest-tundra ecotone in Finish Lapland, where the number of mature seeds and seedlings emerging from the seed bank of E. nigrum ssp. hermaphroditum tended to be higher in the tundra heath than in the coniferousand mountain birch-forest. Disturbance marginally increased the seedling emergence, whereas sowing generally increased the seedling number. The seedling number was lower in the coniferous forest than the other sites [214].

In a warmer climate, with higher $\mathrm{CO}_{2}$ levels $(+200 \mathrm{ppm})$ and a constant likelihood of extreme weather events, E. nigrum ssp. hermaphroditum may be more susceptible to freezing events, which may partially offset the expected enhanced growth with global changes in climate. Hence, freezing damage should be accounted for when predicting changes in growth of alpine plants or changes in community composition under future atmospheric and climate conditions [215]. There are influences of snow depth, ice-formation and frozen ground induced by climate change, as shown for Empetrum, which benefit from shallow fertilization $(10 \mathrm{~cm}$ depth) but not fertilization at the thaw-front at $45 \mathrm{~cm}$ depth [216].

The carbon stock in a plant society is important. Sampling soil $\mathrm{C}$ stocks, soil surface $\mathrm{CO}_{2}$ flux rates and fungal growth rates along replicated natural transition from birch forest (Betula pubescens), through deciduous shrub tundra (Betula nana) to tundra heaths (Empetrum nigrum) near Abisko in Swedish Lapland has demonstrated that organic $\mathrm{C}$ in the organic horizon layer was lower in the shrub and forest than heath (Empetrum). Shrub vegetation had the highest respiration rate, thus suggesting that despite higher rates of $\mathrm{C}$ assimilation, $\mathrm{C}$ turnover was also very high, and there was less $\mathrm{C}$ sequestered in the ecosystem. Growth rates of fungal hyphae increased across the transition from heath to shrub, thus suggesting that the action of mycorrhizal symbionts, in the scavenging of originally bound nutrients, is an important pathway making soil $\mathrm{C}$ available to microbial degradation. The expansion of deciduous shrubs onto potentially vulnerable arctic soils with large stores of $\mathrm{C}$ could therefore represent a positive feedback to the climate system [217].

\subsection{1.d.2. Influences of disturbance}

The species is vulnerable to disturbance and climate change and is locally extinct or decreased in its habitats because of such effects. To cope with these effects, conservation measures are taken at the national and/or state levels in countries such as the USA, Canada and China [64].

Empetrum is a frequently grazed shrub [218]. Disturbance by grazing combined with warming may interact with plant development. Under such conditions, different phenolic compound groups (in the leaves) may vary or even show opposing responses to warming in the tundra. Even when plant phenol concentration does not directly respond to grazing, grazers may have key control over plant responses to changes in the abiotic environment, thus reflecting multiple adaptive purposes of plant phenolics and complex interactions between biotic and the 
abiotic factors [219]. Herbivores could influence plant nutrient uptake and decrease nutrient partitioning of chemical $\mathrm{N}$ forms among plant species. Therefore, decreased niche complementarity among species (including E. hermaphroditum) is potentially important for estimates of the effects of herbivory on plant nutrient availability and species coexistence [220].

Other types of disturbance may lead to decreased cover and takeover by other species. Removing the vegetation and soil organic layers in a coniferous forest, a mountain birch forest and in a tundra heath in Finland has reinforced the proportion of deciduous (V. myrtillus) and graminoids at the expense of the evergreen Empetrum nigrum ssp. hermaphroditum, similarly to $\mathrm{N}$ fertilization $\left(40 \mathrm{~kg} \mathrm{~N}\right.$ haa $^{-1}$ year $\left.^{-1}\right)$, thus suggesting that increasing $\mathrm{N}$ affects the rate rather than the direction of recovery after disturbance [221]. The coverage of dwarf shrubs at 60-year-old military sites in the subarctic mountain area in Finish Lapland, especially of E. nigrum ssp. hermaphroditum (and V. myrtillus), was lower compared to the controls; instead, increased coverage of some graminoids was observed. This confirms the observations of earlier studies indicating that, rather than ecological recovery, the long-term development of vegetation in disturbance areas in high latitudes shows a shift to functionally different plant communities [222]. This is parallel to events in Korea, where the subspecies E. nigrum ssp. japonicum is locally extinct or reduced in its habitats due to direct impacts (frequent wildfire, increasing underground water level, excessive growth of trees, damage from recreation activities, increasing invasive species and accumulation of heavy metals) as well as direct impacts such as global warming [64].

The particularly slow recovery of E. nigrum ssp. hermaphroditum after disturbance in a 14-year period was found in the forest understory on 30 islands in northern Sweden in 1998 [223]. Simulating the extreme winter warming and the effect of $\mathrm{N}$-addition of warmer summers showed that E. nigrum ssp. hermaphroditum failed to recover only after $100 \%$ removal. At $50 \%$ removal, it recovered after seven years if no $\mathrm{N}$ was added; however, when adding $\mathrm{N}$, it recovered in four years [224].

After an outbreak of geometride moths in the birch-forest tundra ecotone, there was a shift in the understory [208] and Empetrum declined to a similar extent to many other species. However, Empetrum differed in its mechanism compared to the others with a rapid browning despite relatively modest feeding damage. The main reason was an additional fungus parasitizing Empetrum, demonstrating the complexity of causes and reactions. Simulated herbivory affected the relationship between deciduous and evergreen dwarf shrubs, most importantly $E$. nigrum ssp. hermaphroditum, which led to a recent shift in the dominant vegetation from deciduous to evergreen. Simulated herbivory caused no effect on GEP (Gross Ecosystem Production) or ER (Ecosystem Recovery), or the total ecosystem $\mathrm{C}$ stocks, indicating that the vegetation shift counteracted the herbivore-induced $\mathrm{C}$ loss from the system [225].

\section{Conclusion}

This review embraces five species including subspecies among the wild berries of the dwarf shrubs. These species are Vaccinium myrtillus, Vaccinium vitis-idaea, Vaccinium uliginosum, Vacciniun oxycoccos and Empetrum nigrum with ssp. nigrum, hermaphroditum and japonicum. They have been and still are collected in the wild, both by local households and industry. The berries have high levels of biological compounds that can improve human health. Despite an increasing interest and demand for these wild berries, domestication attempts are few. These species often grow together and are competitors. Which species will dominate is dependent on soil conditions and small differences. The changing climate and various disturbances will also interfere and may change the distribution pattern of wild berry species and other competing plant species at the same location. Semi-cultivation in the natural habitat could be one solution for a sustainable and commercially viable exploitation of these resources, at least if they are advertised as being "wild". However, they are easily propagated by fresh cuttings and grow on arable land if soil conditions are suitable. This to our knowledge has not yet been done on a large economical scale. 


\section{Acknowledgments}

The study was made possible by internal financing by NIBIO, Division Food and Society, Department of Horticulture, Norway.

\section{Funding}

The authors report no funding.

\section{Conflict of interest}

The authors have no conflict of interest to report.

\section{References}

[1] Paassilta M, Moisio S, Jaakola L, Hãggman H. Voice of the Nordic wild berry industry. Survey among the companies. Oulu university press. 2009; Oulu:65.

[2] Raatikainen M. Estimates of wild berry yields in Finland. Fennica. 1998;136:9-10.

[3] Kellogg, J., Wang, JZ., Flint, C., Ribnicky, D., Kuhn, P., De Mejia, EG., Raskin, I., Lila, MA.,2010 Alaskan Wild Berry Resources and Human Health under the Cloud of Climate Change, Journal of Agricultural and Food Chemistry. 2010; 7:3884-3900.

[4] Prior F. Overview: From Neolithic to Bronze Age, 8000 - 800 BC. 2011; available online: http://www.bbc.co.uk/history/ancient/ british_prehistory/overview_british_prehistory_01.shtml.

[5] Historienet. Hva slags mat spiste vikingene? Bonnier Publications A/S, Oslo, Norway. 2014; Online: http://historienet.no/ sivilisasjoner/vikinger/hva-slags-mat-spiste-vikingene.

[6] Hauge Arild. Familielivet i vikingetida. Arild Hauges runer. 2002; Available on, www.arild hauge.com/familie.htm.

[7] Janick J, Laurens F, Evans K. Genetic alterations associated with the origins of fruit culture. Acta Horticulturae. 2004;663(2):683-91.

[8] Hultén E, Fries M. Atlas of North European vascular plants: North of the tropic of cancer. 2. Taxonomic index to the maps 997-1936, maps 997-1936. Koeltz Scientific Books, Köningsstein Germany. 1987. With the kind permission of Per Koeltz (May 2018).

[9] Rodriguez-Saona C, Vorsa N, Singh AP, Jojnson-Cicalese J, Szendrei Z, Mescher MC and Frost CJ. Tracing the history of plant traits under domestication in cranberries: Potential consequences on anti-herbivore defences. Journal of Experimental Botany. 2011;62(8):2633-44.

[10] Gustavsson BA. Euphytica Genetic variation in horticulturally important traits of fifteen wild lingonberry Vaccinium vitis-idaea L. populations. July 2001, Euphytica. 2001;120(2):173-82. DOI: 10.1023/A:1017550609218

[11] Paal T. Lingonberry (Vaccinium vitis-idaea L.) research in Estonia. An overview. Acta Horticulturae. 2006;715:203-18. DOI: 10.17660/ActaHortic.2006.715.29

[12] Martinussen I, Rohloff J, Uleberg E, Junttila O, Hohtola A, Jaakola L, Häggman H. Climatic effects on bilberry (Vaccinium myrtillus) quality. Latvian Journal of Agronomy. 2009;12:71-4.

[13] Lid J, Lid DT. Norsk flora. Det norske samlaget (7. edition). 2017; pp. 11230. ISBN978-82-521-6029

[14] Bianchi A. Botanical aspects of Vaccinium spp. Proceedings of conference in Trento, Italy. 1988;143-9.

[15] Purgar DD, Šindrak Z, Mihelj D, Voća S, Duralija B. Distribution of the genus Vaccinium in Croatia. Pomologia Croatia. 2007;13(4):219-28.

[16] Glowacki S. The basic raw material of forest fruits in natural stands and plantations in Poland. Norwegian Journal of Agricultural Sciences. 1988;2:151-9.

[17] Pliszka K, Clayton-Greene KA. The blueberry industry and research in Eastern Europe: Review. Acta Horticulturae. 1993;346:41-3.

[18] Liu XT, Zhong Qiu T, Hua L, Qing Hua Z. Status and exploitation of the genetic resources of two species of blueberry. Forestry Research. 1998;11(2):64-8.

[19] Bjedov I, Obratov-Petkovic D, Misik D, Siler B, Aleksic JM. Genetic patterns in range-edge populations of Vaccinium species from the central Balkans: Implications on conservation prospects and sustainable usage. Silva Fennica. 2015;49(4): article id 1283. 
[20] Tonteri T, Salemaa M, Rautio P, Hallikainen V, Korpela L, Merilä P. Forest management regulates temporal change in the cover of boreal plant species. Forest Ecology and Management. 2016;381:115-24.

[21] Losvik MH. The effect of clear-cutting Betula pubescens Ehrh. (birch) on the plant species composition in a subalpine Vaccinium myrtillus-dominated pasture area. Norwegian Journal of Agricultural Sciences. 1993;7(3-4):333-44.

[22] Puchnina LV. Berry yield of Vaccinium uliginosum in Pinega State reserve. Rastitel'nye Resursy. 1990;26(2):179-82.

[23] Wardle DA, Jonsson M. Long-term resilience of above- and belowground ecosystem components among contrasting ecosystems. Ecology. 2014;95(7):1836-49.

[24] Nordløkken M, Berg T, Flaten T. Steinnes E. Essential and non-essential elements in natural vegetation in southern Norway: Contribution from different sources. Science of the Total Environment. 2015;502:391-9.

[25] Singh A, Agrawal M. Acid rain and its ecological consequences. Journal of Environmental Biology. 2008;29(1):15-24.

[26] Moilanen M, Fritze H, Nieminen M, Piirainen S, Issakainen J, Piispanen J. Does wood ash application increase metal accumulation in forest berries and mushroom? Forest Ecology and Management. 2006;226(1/3):153-60.

[27] Nestby R, Martinussen I, Krogstad T, Uleberg E. Effect of fertilization, tiller cutting and environment on plant growth and yield of European blueberry (Vaccinium myrtillus L.) in Norwegian forest fields. Journal of Berry Research. 2014;4:79-95.

[28] Grønflaten LK, Amundsen L, Frank J, Steinnes E. Influence of liming and vitality fertilization on trace element concentrations in Scots pine forest soil and plants. Forest Ecology and Management. 2005;213(1/2/3):261-72.

[29] Binkley D, Högberg P. Tamm review. Revisiting the influence of nitrogen deposition on Swedish forests. Forest Ecology and Management. 2016;368:222-39. DOI: 10.1016/j.foreco.2016.02.035

[30] United States Environmental Protection Agency (EPA). Progress report. 2016. Available online: https://www3.epa.gov/ airmarkets/progress/reports/emissions_reductions.html.

[31] Butler TJ, Likens GE. Acid rain. Pollution. Encyclopædia Brittannia. 2018. Available online: https://www.britannica.com/ science/acid-rain.

[32] Walker JF, Aldrich-Wolfe L, Riffel A, Barbare H, Simpson NB, Trowbridge J, Jumpponen A. Diverse Helotiales associated with the roots of three species of Arctic Ericaean provide no evidence for host specificity. New Phytologist. 2011;191(2):515-27.

[33] Wright RF, Tietema A. Ecosystem response to 9 years of nitrogen addition at Sogndal, Norway. Forest Ecology and Management. 1995;71(1/2):133-42.

[34] Heerwaarden LM van, Toet S, Aerts R. Nitrogen and phosphorous resorption efficiency and proficiency in six sub-arctic bog species after 4 years of nitrogen fertilization. Journal of Ecology. 2003;1(6):1060-70.

[35] Johnson J, Pannatier EG, Carncelli S, Cecchini G, Clarke N, Cools N, Hansen K, Messenburg H, Nieminen TM, Pihl-Karlsson G, Titeux H, Vanguelova E, Verstraeten A, Vesterdal L, Waldner P, Jonard M. The response pf soil solution chemistry in European forests to decreasing acid deposition. Global Change Biology. 2018:1-17. DOI: 10.1111/gbc.14156

[36] Ransijn J, Kepfer-Rojas S, Verheyen K, Riis-Nielsen T, Schmidt IK. Hints for alternative stable states from long-term vegetation dynamics in an unmanaged heathland. Journal of Vegetation Science. 2015;26(2):254-66.

[37] Jeffers ES, Bonsall MB, Watson JE, Willis KJ. Climate change impacts on ecosystem functioning: Evidence from an Empetrum heathland. New Phytologist. 2012;193(1):150-64.

[38] Vuorinen KEM, Oksanen L, Oksanen T, Pyykönen A, Olofsson J, Virtanen L. Open tundra persist, but arctic features decline vegetation changes in the warming Fennoscandiian tundra. Global Change Biology. 2017;23(9):3794-807.

[39] Wardle DA, Gundale MJ, Jäderlund A, Nilsson MC. Decoupled long-term effects of nutrient enrichment on aboveground and belowground properties in subalpine tundra. Ecology. 2013;94(4):904-19.

[40] Hammer D. How advanced glycation end products cause you to AGE. 2018. Available online: http://www.aging-nomore.com/advanced-glycation-end-products.html.

[41] Harris CS, Cuerrier A, Lamont E, Haddad PS, Arnason JT, Bennet SAL, Johns T. Plant Foods for human Nutrition. 2014;69(1):71-7.

[42] Battino M, Beekwilder, Denoyes B. Bioactivitiews of berries relevant to human health. Nutrition reviewes. 2009;67(1):145-50.

[43] Pan DD, Mei XM. Antioxydant activity of an exopolysaccharide purified from Lactococcus lactis subsp. Lactis 12. Carbohydrate Polymers. 2010;80(3):908-14.

[44] Plotnikov DA and Shmidt AS. Stocks of wild medical, berry and fruit plants in the Parabelsk district of Tomsk region. Rastitel'nye Resursy. 1988;24(2):177-82.

[45] Alvarez-Suarez JM, Dekansi D, Ristic S, Radonjic NV, Petronijevic ND, Giampieri F, Astolfi P, Gonzáles-Paramás AM, SantosBuelga C, Tulipani S, Quiles JL, Mezzetti B, Battino M. Strawberry polyphenols attenuate ethanol-induced gastric lesion in rats by activation of antioxudant enzymes and attenuation of MDA increase. Plos One. 2011;6(10):11.

[46] Mazzoni L, Perez-Lopez P, Giampieri F, alvarez-Suarez JM, Gasparrini M, Tamara Y, Forbes-Hernandez, Quiles JL, Mezzetti B, Battino M. The genetic aspects of berries: From field to health. Journal of Scientific Food Agriculture. 2015; pp. 7. Published online in wileyonlinelibrary.com, DOI: 10.1002/jsfa.7216 
[47] Giampieri F, Alvarez-Suarez JM, Gasparrini M, Forbes-Hernandez TY, Afrin S, Bompadre S, Rubini C, Zizzi A, Astolfi P, SantosBuelga, Gonzáles-Parmás AM, Quiles JL, Mezzetti B, Battino M. Strawberry consumption alleviates doxurubicin-induced toxity by suppressing oxidative stress. Food Chemistry Toxicol. 2016;94:128-37. DOI: 10.1016/j.fct.2016.06.003

[48] Giampieri F, Gasparrini M, Forbes-Hernandez TY, Mazzoni L, Capocasa F, Sabbadini S, Alvarez.Suarez JM, Afrin S, Rosati C, Pandolfini T, Molesini B, Sánches-Villa JF, Amaya I, Mezzetti B, Battino M. Overexpression of the anthocyanidin synthase gene in strawberry enhances antioxidant capacity and cytotoxic effects on human hepatic cancer cells. Journal of Agricultural Food Chemistry. 2018;66(3):581-92.

[49] Giampieri F, Alvarez-Suarez JM, Mazzoni L, Forbes-Hernandez TY, Gasparrini M, Ana M. Paramás G, Santos-Buelga C, Quiles JL, Bompadre S, Mezzetti B, Battino M. Polyphenol-Rich Strawberry Extract Protects Human Dermal Fibroblasts against Hydrogen Peroxide Oxidative Damage and Improves Mitochondrial Functionality. Molecules. 2014;19:7798-816. DOI: 10.3390/molecules 19067798

[50] Olas B. The multifunctionality of berries toward blood platelets and the role of berry phenolics in cardiovascular disorders. Platelets. 2017;28(6):540-9. DOI: 10.1080/09537104.2016.1235689

[51] Dudonné S, Dubé P, Ahne FF, Pilon G,Marette A, Lemire M, Harris C, Dewailly E, Desjardins Y. Comprehensive analysis of phenolic compounds and abscisic acid profiles of twelve native Canadian berries. Journal of Food Composition and Analysis. 2016;44:214-24.

[52] Matvaretabellen. Content of biological compounds in berries. Available online: http://www.matvaretabellen.no/.

[53] Braga PC, Antonacci R, Wang N, Lattuada N. Comparative antioxidant activity of cultivated and wild Vaccinium species investigated by EPR, human neutrophil burst and COMET assay. European Review for Medical and Pharmacological Sciences. 2013;17:1987-99.

[54] Grace MH, Esposito D, Dunlap KL, Lila MA. Comparative analysis of phenolic content and profile, antioxidant capacity and anti-inflammatory bioactivity in wild Alaskan and commercial Vaccinium berries. Journal of Agricultural Food Chemistry. 2014;62(18):4007-17.

[55] Kelly E, Vyas P, Weber JT. Biochemical properties and neuroprotective effects of compounds in various species of berries. Molecules. 2018;23(1):26.

[56] Hoed VV, Clercq ND, Echim C, Andjelkovic M, Leber E, Dewettinck K, Verhe R. Berry seeds: A source of speciality oils with high content of bioactives and nutritional value. Journal of Food Lipids. 2009;16:33-49.

[57] Yang B, Koponen J, Tahvonen R, Kallio H. Plant sterols in seeds of two species of Vaccinium (V. myrtillus and V. vitis-idaea) naturally distributed in Finland. European Food Research Technology. 2003;216:34-8.

[58] Szakiel A, Paczkowski C, Pensec F, Bertsch C. Fruit cuticular waxes as a source of biologically active triterpenoids. Phytochemical Reviews. 2012;11:263-84.

[59] Klavins L, Kviesis J, Steinberga I, Klavina L and Klavins M. Gas chromatography-mass spectrometry study of lipids in northern berries. Agronomy Research. 2016;14(S2):1328-46.

[60] Stenset NE, Lutnæs PN, Bjarnadóttir V, Dahle B, Fossum KH, Jigsved P, Johansen T, Neumann W, Opseth O, Rønning O, Steyaert SMJG, Zedrosser A, Brunberg S, Swenson JE. Seasonal and annual variation in the diet of brown bears Ursus arctos in the boreal forest of southcentral Sweden. Wildlife Biology. 2016;22(3):107-16.

[61] Hertel AG, Steyaert SMJG, Zedrosser A, Mysterud A, Lodberg-Holm HK, Gelink HW, Kindberg J, Swenson JE. Bears and berries: Species-specific selectiv foraging on a patchily distributed food resource in a human-altered landscape. Behavioral Ecology and Sociobiology. 2016;70(6):831-42.

[62] Catoni C, Schaefer HM, Peters A. Fruit for health: The effect of flavonoids on humoral immune response and food selection in a frugivorous bird. Functional Ecology. 2008;22:649-54. DOI:10.1111/j.1365-2435.2008.01400.x

[63] Gwynn-Jones D, Jones AG Watyerhouse A, Winters A, Comont D, Scullion J, Gardias R, Graee BJ, Lee JA, Callaghan TV. Enhanced UV-B and elevated CO2 impacts sub-Arctic shrub berry abundance, quality and seed germination. Ambio. 2012;41(3):256-68. DOI: $10.1007 / \mathrm{s} 13280-012-0311-4$

[64] Kim CS, Han AH, Koh JG, Byun GO. Review on the taxonomic and biogeographic characteristics of an arctic-alpine species, Empetrum nigrum var. japonicum in Mt. Halla, Korea. KFRI Journal of Forest Science (Seoul). 2005;68:128-36.

[65] Witte LC de, Armbruster GFJ, Gielly L, Taberlet P, Stöcklin J. AFLP markers reveal high clonal diversity and extreme longevity in four key arctic-alpine species. Molecular Ecology. 2012;21(5):1081-97.

[66] Aerts R, Callaghan TV, Dorrepaal E, Logtestijn rsp van, Cornelissen JHC. Seasonal climate manipulations result in species-specific changes in leaf nutrient levels and isotopic composition in a sub-arctic bog. Functional Ecology. 2009;23(4):680-8.

[67] Auffret AG, Meineri E, Bruun HH, Ejrnæs R, Graae BJ. Ontogenetic niche shifts in three Vaccinium species on a sub-alpine mountain side. Plant Ecology\& Diversity. 2010;3(2):131-9.

[68] Nygaard PH, Ødegaard T. Sixty years of vegetation dynamics in a south boreal coniferous forest in southern Norway. Journal of Vegetation Science. 1999;10(1):5-16.

[69] Alsos IG, Eidesen PB, Erich D, Skrede I, Westergaard K, Jacobsen GH, Landvik JY, Taberlet P, Brochmann C. 2007. Frequent long distance dispersal in the changing Arctic. Science. 2007;316:1606-9. 
[70] Koller EK, Press MC, Callaghan TV, Phoenix GK. Tight coupling between shoot level foliar N and P, leaf area, and shoot growth in Arctic dwarf shrubs under simulated climate change. Ecosystems. 2016;19:326-38.

[71] Graglia E, Jonasson S, Michelsen A, Schmidt IK. Effects of shading, nutrient application and warming on leaf growth and shoot densities of dwarf shrubs in two arctic-alpine plant communities. Ecoscience. 1997;4(2):191-8.

[72] Raatikainen M. Vaccinium myrtillus yields and environmental factors. Aquilo Series Botanica. 1993;31:21-6.

[73] Wallenius TH. Yield variations of some commom wild berries in Finland in 1956-1996. Annales Botanici Fennici. 1999;36:299-314.

[74] Krebs CJ, Boonstra R, Cowcill K, Kenney AJ. Climatic determinants of berry crops in the boreal forest of the southwestern Yukon. Botany. 2009;87(2):401-8.

[75] Fröborg H. Pollination and seed production in five boreal species of Vaccinium and Andromeda (Ericaceae). Canadian Journal of Botany. 1996;74(9):1363-8.

[76] Hartley AE, Neill C, Melillo JM, Crabtree R, Bowles FP. Plant performance and soil nitrogen mineralization in response to simulated climate change in subartic dwarf shrub heath. Oikos. 1999;86(2):331-43.

[77] Kudo G, Suzuki S. Warming effects on growth, production, and vegetation structure of alpine shrubs; a five-year experiment in northern Japan. Oecologia. 2003;135(2):280-7.

[78] Witte LC, Stöcklin J. Horizontal growth in arctic-alpine clonal plants is not affected by climate variability among regions. Plant Ecology \& Diversity. 2011;4(4):329-40.

[79] Anadon-Rossel A, Hasibeder R, Palacio S, Mayr S, Ingrisch J, Ninot JM, Nogués S, Bahn M. Short-term carbon allocation dynamics in subalpine dwarf shrubs and their responses to experimental summer drought. Environmental and Experimental Botany. 2017;141:92102.

[80] Suzuki S, Kudo G, Omasa K, Nouchi I, Goto E, Oki K, Shimizu Y, Kok LJ de, Grill D, Stulen I. Resource allocation pattern under simulated environmental change and seedlings establishment of alpine dwarf shrubs in a mid-latitude mountain. Phython (Horn). 2005;45(4):409-14.

[81] Kudo G, Suzuki S. Relationship between flowering phenology and fruit-set of dwarf shrubs in alpine fellfields in northern Japan: A comparison with a subarctic heathland in northern Sweden. Arctic, Antartic and Alpine Research. 2002;34(2):185-90.

[82] Grimashevich V. Climatically determinate projections of resources of Vaccinium species in Belarus to 2050. Agronomijas Vestis. 2009;12:29-34.

[83] Butkene ZP, Butkus VF. Biological and biochemical characteristics of Vaccinium uliginosum. 1. Phenology, shoot growth, and flowering and fruiting habit. Lietuvos TSR Mokslu Akademijos Darbai, C. 1978;1(81):41-8.

[84] Kuprian E, Briceno VF, Wagner J, Neuner G, Wisniewski M, Gusta LV. Ice barriers promote supercooling and prevent frost injury in reproductive buds, flowers and fruits of alpine dwarf shrubs throughout the summer. Environmental and Experimental Botany. 2014;106:4-12.

[85] Anadon-Rossel A, Ninot J, Palacio S, Grau O, Nogués S, Navarro E, Sancho MC, Carillo E. Four years of experimental warming do not modify the interaction between subalpine shrub species. Oecologia. 2017;183(4):1167-81.

[86] Bienau MJ, Hattermann D, Kröncke M, Kretz L, Otte A, Eiserhardt WL, Milbau S, Graae BJ, Durka W, Eckstein RL, Feit U, Korn H. Shoot morphology, flowering phenology and local adaptation in Empetrum hermaphroditum, in a key type boreal-Arctic ecosystem, along snowy cover gradients. BfN- Skripten. 2015;397:107-12.

[87] Palacio S, Lenz A, Wipf S, Hoch G, Rixen C. Bud freezing resistance in alpine shrubs across snow depth gradients. Science of the Total Environment. 2015;502:391-9.

[88] Preece C, Phoenix GK, Impact of early and late winter icing events on sub-arctic dwarf shrubs. Plant Biology. 2014;16(1):125-32.

[89] Wheeler JA, Hoch G, Cortés AJ, Sedlacek J, Wipf S, Rixen C. Increased spring freezing vulnerability for alpine shrubs under early snowmelt. Oecologia. 2014;175(1):219-29.

[90] Schollert M, Kivimäenpää M, Rinnan R, Wiley-Blackwell. Climate change alters leaf anatomy, but has no effects on volatile emissions from Arctic plants. Plant, Cell and Environment. 2015;38(10):2048-60.

[91] Schollert M, Kivimäenpää M, Michelsen A, Blok D, Rinnan R. Leaf anatomy, BVOC emission and CO2 exchange of arctic plants following snow addition and summer warming. Annals of Botany. 2017;119(3):433-45.

[92] Atkinson R, Erey J. Gas-phase tropospheric chemistry of biogenic volatile organic compounds: A review. Atmospheric Environment. 2003;37(2):197-219.

[93] Gouw J de, Jimenez JL. Organic aerosols in the Earth's atmosphere. Environmental Science \& Technology. 2009;43(20):7614-8.

[94] Fantaye CS. The roles of plant sesquiterpenes in defense against biotic and abiotic stresses. Dissertation. Biologish-Pharmazeutishen Fakultãt der Friedrich-Schiller-Universität Jena, Germany. pp. 144.

[95] Faubert P, Tiiva P Michelsen A, Rinnan A, Ro-Poulsen H, Rinnan R. The shift in plant species composition in a subarctic mountain birch forest floor due to climate change would modify the biogenic volatile organic compound emission profile. Plant and Soil. 2012;352(1/2):199-215. 
[96] Handa IT, Hagedorn F, Hättenschwiler S. No stimulation in root production in response to 4 years in situ $\mathrm{CO} 2$ enrichment at the Swiss treeline. Functional Ecology. 2008;22(2):348-58.

[97] Dawes MA, Hagedorn F, Handa IT, Streit K, Ekblad A, Rixen C, Körner C, Hättenschwiler S. An alpine treeline in a carbon dioxide-rich world; synthesis of a nine-year free-air carbon dioxide enrichment study. Oecologia. 2013;171(3):623-37.

[98] Dawes MA, Schleppi P, Hättenschwiler S, Rixen C, Hagedorn F. Soil warming opens the nitrogen cycle at the alpine treeline. Global Change Biology. 2017;23(1):421-34.

[99] Katerova Z, Todorova D, Tasheva K, Sergiev I. Influence of ultraviolet radiation on plant secondary metabolite production. Genetics and Plant Physiology. 2012;2 (3-4):113-44.

[100] Phoenix GK, Gwynn-Jones D, Callaghan TV, Sleep D, Lee JA. Effects of global change on a sub-Arctic heath: Effects of enhanced UV-B radiation and increased summer precipitation. Journal of Ecology. 2001;89:256-67.

[101] Smerdjieva SI, Sheffield E, Phoenix GK, Gwynn-Jones D, Callaghan TV, Johnson GN. Contrasting strategies for UV-B screening in sub-Arctic dwarf shrubs. Plant, cell and Environment. 2002;26(6):957-64.

[102] Jones AG, Bussell J, Winters A, Scullion J, Gwynn-Jones D. The functional quality of decomposing litter outputs from an Arctic plant community is affected by long-term exposure to enhanced UV:B. Ecological indicators. 2016;60:8-17.

[103] Vowles T, Gunnarsson B, Molau U, Hickler T, Klemedtsson L, Björk RG. Expansion of deciduous tall shrubs but not evergreen dwarf shrubs inhibited by reindeer in Scandes mountain range. Journal of Ecology (Oxford). 2017;105(6):1547-61.

[104] Song GQ, Hancock JF. Chapter 10 Vaccinium. In: Kole C. (ed.) Wild Crop Relatives: Genomic and Breeding Resources, temperate fruits. Springer-Verlag, Berlin, Heidelberg. 2011;197-221. DOI: 10.1007/978-3-642-16057-8_10

[105] Hummer K, Bassil NV, Rodríquez HV and Olmstead JW. Vaccinium species ploidy assessment. Acta Horticulturae. 2015;1101:199203. DOI: 10.17660/ActaHortic. 2015.1101.30

[106] Gerdol R. Growth performance of two deciduous Vaccinium species in relation to nutrient status in a subalpine heath. Flora (Jena). 2005;200(2):168-74.

[107] Vasilevich VI. Sphagnum pine forests in the Eastern Europe. Botanicheskii Zhurnal. 2012;97(4):452-64.

[108] Erstad KJ, Burghardt W, Kulhavý J, Lomský B. Fertilizing and liming in a heather area of Norway. Journal of Forest Science. 2006;52:52-7.

[109] Nestby R, D Percival, I Martinussen, N. Opstad and J. Rohloff. The European Blueberry (Vaccinium myrtillus L.). A Review. The European Journal of Plant Science and Biology. 2011;2011 Global Science Books; pp. 11.

[110] Ritchie JC. Biological flora of the British Isles: Vaccinium myrtillus L. Journal of Ecology. 1956;44:291-9.

[111] Coudun C and Gégout JC. Quantitative prediction of the distribution and abundance of Vaccinium myrtillus with climate and edaphic factors. Journal of Vegetation Science. 2007;18:517-24.

[112] Turtiainen M, Miina J, Salo K, Hotanen JP. Modelling the coverage and annual variation on bilberry yield in Dudonné Finland. Silva Fennica. 2016;50(4):12.

[113] Flower-Ellis JGK. Age structure and dynamics in stands of European blueberry (Vaccinium myrtillus L.). PhD dissertation. Res. Notes 9. Royal College For. Stockholm. 1971;108.

[114] Eriksson O, Fröborg H. 'Windows of opportunity' for reqruitment in long lived clonal plants: Experimental studies of seedling establishment in Vaccinium shrubs. Canadian Journal of Botany. 1996;74(9):1369-74.

[115] Nin S, Petrucci AW, Del Bubba M, Ancillotti C, Giordani E. Effects of environmental factors on seed germination and seedling establishment in bilberry (Vaccinium myrtillus L.). Scientica Horticultura. 2017;226:241-9.

[116] Baskin CC, Milberg P, Andersson L, Baskin JM. Germination studies of three dwarf shrubs (Vaccinium, Ericaceae) of northern hemisphere coniferous forest. Canadian Journal of Botany. 2000;78(12):1552-60.

[117] Turtianen M, Salo K, Saastamoinen O. Variations of yield and utilization of bilberries (Vaccinium myrtillus L.) and cowberries (Vaccinium vitis-idaea L.) in Finland. Silva Fennica. 2011;45(2):237-51.

[118] Mukeriya G, Philainen S, Linkosalo T, Mäkipää R. Abstract, In: Towards a new era of forest science in the boreal region. Natural Resources Institute Finland (Luke). 2015:112.

[119] Eckerter T, Buse J, Förschler M, Pufal G. Additive positive effects of canopy openness on European bilberry (Vaccinium myrtillus) fruit quantity and quality. Forest Ecology and Management. 2019;433:122-30. DOI: 10.1016/j.foreco.2018.10.059

[120] Anadon-Rossel A, Palacio S, Nogués S, Ninot JM. Vaccinium myrtillus stands show similar structure and functioning under differen scenarios of coexistence at the Pyrenean treeline. Plant Ecology. 2016;217(9):1115-28.

[121] Nestby R, Krogstad T, Hovstad KA. Botanical survey of two Norwegian forest fields, dominated by Eyropean blueberry (Vaccinium myrtillus L.). Acta Horticulturae. 2017;1180:177-87. DOI: 10.17660/ActaHortic.2017.1180.24

[122] Nestby R, Krogstad T, Joner E, Vohnik M. The effect of NP fertilization on European blueberry (Vaccinium myrtillus L.) development on cultivated land in mid-Norway. Journal of Berry Research. 2014;4:147-57. DOI: 10.3233/JBR-140077 
[123] Figal Sergio d. P, Characterization of variation in plant growth and fruit production in a Danish clonal genepool of European blueberries (Vaccinium myrtillus L.) as a basis for identification of superior genotypes for future cultivation. Aarhus University. Faculty of Science and Technology. Master Thesis. 2017:80.

[124] Petersen ME. Vilde blåbær kan snart blive en dansk kommerciel afgrøde. Bærog Frukt. 2017;616:17.

[125] Vohnik M, Sadowsky JJ, Kohout P, Lhotáková Z, Nestby R, Kolarík. Novel root-fungus symbiosis in Ericaceae: Sheated ericoid mycorrhiza formed by a hitherto undescribed Bacidiomycete with affinities to Trechisporales. Plos One. 2012;7(6):e39524:16.

[126] Selås V, Sonerud GA, Framstad E, Kålås JA, Kobro S, Pedersen HB, Spidsø TK, Wiig Ø. Climatic change in Norway: warm summers limit grouse reproduction. Population Ecology. 2011;53:361-71. DOI: 10.1007/s10144-010-0255-0

[127] Selås V, Sønsteby A, Heide OM, Opstad N, 2015. Climatic and seasonal control of annual growth rythm and flower formation in Vaccinium myrtillus (Ericaceae), and the impact on annual variation in berry production. Plant Ecology and Evoluation. 2015;148(3):350-60. DOI: /105091/plecevo.2015.1110

[128] Giordani E, Biricolti S, Ancillotti C, Petrucci WA, Gori M, Calistri E, Orlandini S, Furlanetto S, Bubba M Del. Genetic diversity and changes in phenolic contents and antiradical activity of Vaccinium myrtillus berries from its southernmost growing area in Italy. Genetic Resources Crop Evolution. 2018;65:1173-86. DOI: 10.1007/s10722-018-0605-x

[129] Uleberg E, Rohloff J, Jaakola L, Trost K, Juntitila O, Häggman H, Martinussen I. Effects of temperature and photoperiod on yield and chemical composition of northern and southern clones of bilberry (Vaccinium myrtillus L.). Journal of Agricultural Food Chemistry. 2012;60:10406-14.

[130] Zoratti L, Karppinen K, Escobar AL, Häggman H, Jaakola L. Light-controlled flavonoid biosynthesis in fruits. Frontier in Plant Science. 2014;5(534):16.

[131] Zoratti L, Sarala M, Carvalho E, Karppinen K, Martens S, Giongo L, Häggman H, Jaakola L. Monochromatic light increases anthocyanin content during fruit development in bilberry. Plant Biology. 2014;14(377):10. Available online: http://www.biomedcentral.com/1471-2229/14/377.

[132] Zoratti L, Klemettilä H, Jaakola L. Bilberry (Vaccinium myrtillus L.). Ecotypes. Nutritional Composition of Fruit Cultivars. 2016:1:8399. DOI: 10.1016/B978-0-12-408117-8.00004-0

[133] Rohloff J, Uleberg E, Nes A, Krogstad T, Nestby R, Martinussen I. Nutritional composition of bilberries (Vaccinium myrtillus L.) from forest fields in Norway - Effects of geographic origin, climate, fertilization and soil properties. Journal of Applied Botany and Food Quality. 2015;(88):274-87. DOI: 10.5073/JABFQ.2015.088.040

[134] Barizza E, Guzzo F, Fanton P, Lucchini G, Sacchi GA. Lo Sciavo F, Nasciembene J. Nutritional profile and productivity of bilberry (Vaccinium myrtillus L.) in different habitats of a protected area of the eastern Italian Alps. Journal of Food Science. 2013;78(5):673-8. DOI: $10.1111 / 1750-3841.12120$

[135] Lohachoompol V, Srzednicki G, Craske J. The change of total anthocyanins in blueberries and their antioxidant effect after drying and freezing. Journal of Biomedical Biotechnology. 2004;5:248-52.

[136] Blethen C, Miles C, Alleman GP. Lingonberries. An aromatic, tart fruit. Washington State University, 2 pp. Available online: http://agsyst.wsu.edu/lingonberriesbroc.pdf

[137] Chester AL, McGraw JB. Effects of nitrogen addition on the growth of Vaccinium uliginosum and Vaccinium vitis-idaea. Canadian Journal of Botany. 1983;61(9):2316-22.

[138] Butkus V, Bandzaitiene Z, Butkiene Z. Effect of mulching on growth and fruiting of cultivated lingonberries (Vaccinium vitis-idaea L.) and bog blueberries (V. uliginosum L.). Acta Horticulturae. 1989;241:265-9.

[139] Kivimäki AS, Siltari A, Ehlers PI, Korpela R, Vapaatalo H. Lingonberry juice lowers blood pressure of spontaneously hypertensive rats (SHR). Journal of Functional Foods. 2013;3:1432-40.

[140] Davidson E, Zimmermann BF, Jungfer, E, Chrubasik-Hausmann S. Prevention of Urinary Tract Infections with Vaccinium Products. Phytother. Res. 2014;28:465-70. DOI:10.1002/ptr.5047

[141] Fan ZL, Wang ZY, Zuo LL, Tian SQ. Protective Effect of Anthocyanins from Lingonberry on Radiation-induced Damages. International Journal of Environmental Research and Public Health. 2012;9(12):4732-43. DOI: 10.3390/ijerph9124732

[142] Lundell R, Saarinen T, Hänninen H. Effects of snowmelt on the springtime photosynthesis of the evergreen dwarf shrub Vaccinium vitis-idaea. Plant Ecology \& Diversity. 2010;3:121-30.

[143] Saario M. Fresh lingonberry quality as affected by storage conditions and packing. Journal of Food Quality. 2000;23:453-63.

[144] Haffner K, Rosenfeld HJ, Sundell HA. Postharvest quality of highbush blueberries after storage in cold store and modified atmosphere packaging. In COST 94, Report on Proceedings of the Workshop Post Harvest Treatment of Fruit and Vegetables, September (eds, DeBaerdemaeke J, McKenna B, Janssen M, Thompson A, Artés Calero F, Höhn E, Somogui Z). 1993:215-24.

[145] Kader AA. Postharvest biology and technology: An overview. In Postharvest Technology of Horticultural Crops (ed. Kader AA). Publication 3311, University of California, Davis, CA. 1992:15-20.

[146] Heimuber B, Herrmann K. Benzoe-, phenylessig-, 3-phenylpropan- und zimtsäure sowie benzonylglucosen in einigen obst- und Früctgemüsearten. Deutsce Lebensmittel Rundschau. 1990;86(7), 205-9. 
[147] Alsos IG, Spjelkavik S, Engelskjøn T. Seed bank size and composition of Betula nana, Vaccinium uliginosum, and Campanula rotundifolia habitats in Svalbard and northern Norway. Canadian Journal of Botany. 2003;81(3):220-31.

[148] Sizykh A, Gritsenyuk A, Shekhovtsov A. Pine forest with undergrowth of pine (Pinus sylvestris L.) and cedar (Pinus sibirica Du Tour) in eolian sands of the central part of lake Baikal eastern coast. International Journal of Ecosystems and Ecology Science. 2017;7(3):445-52.

[149] Natural Resources Conservation Service (NRCS). Managing wild bog blueberry, lingonberry, cloudberry and crowberry stands in Alaska. NRCS and University of Alaska, Fairbanks. 2006:12. Available online: http://www.uaf.edu/files/ snre/Berry_Management.pdf.

[150] Chapin FS. Nitrogen and phosphorus nutrition sand nutrient cycling by evergreen and deciduous understory shrubs in an Alaskan black spruce forest. Canadian Journal of Forest Research. 1983;13(5):773-81.

[151] Kummerow J. Root surface/leaf area ratios in arctic dwarf shrubs. Plant and Soil. 1983;71:395-9.

[152] Gu DZ, Gao HD, Gu MY, Zhu JY, Jiang YT. In vitro culture and plant regeneration system of Vaccinium uliginosum. Forest Research, Beijing. 2009;22(2):226-9.

[153] Xu HJ, Shen G, Shou L, Zhang Y. Habitat classification and ecological factors analysis of Vaccinium uliginosum. Journal of Northeast Forestry University. 2013;41(1):59-6267.

[154] Granheim PO, Brække FH. Vegetation changes on a soligenous mire complex after fertilization and liming. Norsk Institutt for Skogforskning, Ås, Norway, Rapport fra Skogforsk. 1993;11:15.

[155] Bai YC, Hou ZX, Wang C, Yang JF, Yang L. Nutritional characteristics in leaf, root and root soil of Vaccinium uliginosum in Yhr greater Xing'an mountains. Natural Science Edition. 2017;45(7):115-124,133.

[156] Körner C. Effects of chemical fertilizers on alpine dwarf shrubs. Verhandlungen der Gesellschaft für ökologie. 1984;12:123-36.

[157] Michelsen A, Graglia E, Schmidt IK, Jonasson S, Sleep D, Quarmby C. Differential responses of grass and of dwarf shrub to long-term changes in soil microbial biomass $\mathrm{C}, \mathrm{N}$ and $\mathrm{P}$ following factorial addition of NPK fertilizer, fungicide and labile carbon to a heath. New Phytologist. 1999;143(3):523-38.

[158] Körner C. High elevation pioneer plants are sensitive to mineral nutrient addition. Basic Applied Ecology. 2002;3:39-47.

[159] Mayer C, Michez D, Chyzy A, Brédat E, Jackuemart AL. The abundance and pollen foraging behaviour of bumble bees in relation to population size of whortleberry (Vaccinium uliginosum). Plos ONE. 2012;7(11):e50353.

[160] Xu DX, Xia XY, Xu N, An LJ. Isolation and identification of a novel endophytic bacterial strain with antifungal activity from the wild blueberry Vaccinium uliginosum. Annales of Microbiology. 2007;57(4):673-6.

[161] Xu DK, Xia XY, Wei LJ, He JH, An LJ. Study on chitinase-producing endophytic bacterium with antagonistic activity from Vaccinium uliginosum. Journal of Zhejiang University (Agriculture and Life Sciences). 2009:35(4):395-400

[162] Graae BL, Alsos IG, Ejrnaes R. The impact of temperature regimes on development, dormancy breaking and germination of dwarf shrub seeds from arctic, alpine and boreal sites. Plant Ecology. 2008;198:275-84. DOI: 10.1007/s1|1258-008-9403-4

[163] Lozan A, Spitzer K, Jaros J. Isolated peat bog habitats and their food connections: Parasitoids (Hymenoptera: Ocheumonoidea) and their lepidopteran hosts. Journal of Insect Conservation. 2012;16(3):391-7.

[164] Kim MJ, Choung SY. Mixture of polyphenols and anthocyanins from Vaccinium uliginosum L. alleviates DNCB-induced atopic dermatitis in NC/Nga mice. Evidence-based Complementary and Alternative Medicine. 2012;2012: ID 461989.

[165] Zu XY, Zhang ZY, Zhang XW, Masahiro Y, Yang YN. Anthocyanins extracted from Chinese blueberry (Vaccinium uliginosum L.) and its anticancer effects on DLD-1 and COLO205 cells. Chinese Medical Journal (Beijing). 2010;123(19):2714-9.

[166] Liu XT, Gao F, Ji B, Wang R, Yang J. Liu H, Zhou F. Anthocyanins-rich extract of wild Chinese blueberry protects glucolipotoxityinduced INS832(123 $\beta$-cell against dysfunction and death. Journal of Food Science Technology. 2015;52(5):3022-9. DOI: 10.1007/s13197-014-1379-6

[167] Gorbunov AB, Paal T. Bog blueberry - a new horticultural crop. Metsanduslikud Uurimused. 1998;30:54-60.

[168] Kim YH, Bang CY, Won EK Kim JP, Choung SY. Antioxidant activities of Vaccinium uliginosum L. extracts and its active components. 2009;12(4):885-92.

[169] Colak N, Torun H, Gruz J, Strnad M, Hermosin-Gutiérrez I, Haylrlloglu-Ayaz S, Ayaz FA. Bog bilberry phenolics, antioxidant capacity and nutrient profile. Food Chemistry. 2016;201:339-49.

[170] Masuoka C, Yokoi K, Komatsu H, Kino J, Nohara T, Ono M. Two novel antioxidant ortho-benzoyloxyphenyl acertic acid derivatives from the fruit of Vaccinium uliginosum. Food Science and Technology Research. 2007;13(3):215-20.

[171] Rupasova ZA, Yakovlev AP, Vasilevskaya TI, Varavina NP, Krinitskaya NB. Pecularities of accumulation of useful substances in blueberry (V. uliginosum L.) berries while applying mineral fertilizers to exploited peat bog in Belarus. Preceedings of the National Academy of Science of Belarus, Agrarian Series. 2011;1:51-6. 
[172] Buse J, Boch S, Hilgers J, Griebeler EM. Conservation of threatened habitat types under future climate change - Lessons from plant-distribution models and current extinction trends in southern Germany. Journal for Nature Conservation. 2015;27: $18-25$.

[173] Gorsuch DM, Oberbauer SF, Fisher JB. Comparative vessel anatomy of arctic deciduous and evergreen dicots. American Journal of Botany. 2001;88(9):1643-9.

[174] Jiang XJ, Hu YL, Han JQ, Zhou YM. Effects of warming on carbon, nitrogen and phosphorous stoichiometry in tundra soil and leaves of typical plants. Chinese Journal of Plant Ecology. 2014;38(9):941-8.

[175] Narita K, Harada K, Saito K, Sawada Y, Fukuda M, Tsuyuzaki S. Vegetation and permafrost thaw depth 19 years after a tundra fire in 2002, Seward Peninsula, Alaska. Arctic, Antarctic and Alpine Research. 2015;47(3):547-59.

[176] Matthews RF, Robin F. Vaccinium oxycoccos. In: Fire Effects Information System. U.S. Department of Agriculture, Forest-Service, Rocky Mountain Research Station, Fire-Sciences-Laboratory. 1992; Available online: www.fs.fed.us/database/ feis/plants/shrub/vacoxy/all.html

[177] Michalojc Z and Koster M. Effect of fertilization and mycorrhization on growth and nutritional status of cranberry (Vaccinium macrocarpon Ait.) in the nursery. Journal of Horticultural Research. 2015;23(1):49-56.

[178] Swieczkowska A, Kaweci Z, Stanys V. The influence of fertilizers on Vaccinium macrocarpon Ait. Growth and yielding. Zemes u kio Mokslai. 2003;4:76-81.

[179] Karlsons A, Osvalde A. Nutrient status of the American cranberries and wild cranberries in producing plants and natural bogs of Latvia. Agronomijas Vestis. 2008;10:222-7.

[180] Zafra-Stone S, Yasmin T, Bagchi M, Chatterjee A, Vinson JA, Bagchi D. Berry anthocyanins as novel antioxidants in human health and disease prevention. Molecular Nutrition \& Food Research. 2007;51:675-83.

[181] Balan BJ, Lewicki S, Siwicki AK, Stelmasiak M, Skopinski P, Skopinska-Rozewska E, Wasiutynski A, Zdanowski R. Morphometric abnormalities in spleen and kidney of the progeny of mice fed American cranberry extract (Vaccinium macrocarpon) during pregnancy and lactation. Polish Journal of Veterinary Sciences. 2017;20(1):57-65.

[182] Zhan F, Xiao CR. Mechanism of cranberry for prevention of urinary tract and its development in nutrition food. Journal of Food Safety and Quality. 2016;7(9):3597-601.

[183] Foito A, McDougall GJ, Stewart D. Evidence for health benefits of berries. Annual plant reviews. 2018;1:1-43. Available online: http://onlinelibrary.wiley.com DOI: 10.1002/9781119312994.apr06000

[184] Karlsons A, Osvalde A, Nollendorfs V. Research on the mineral composition of American cranberries and wild Cranberries in Latvia. Agronomijas Vestis. 2009;(12):65-71.

[185] Dorofejeva K, Rakcejeva T, Kviesis J and Skudra L. Composition of vitamins and amino acids in Latvian cranberries. Foodbalt. 2011:153-8.

[186] Ruse K, Rakcejeva T. Physical and chemical parameters of Latvian fresh cranberries. Foodbalt. 2014:167-71.

[187] Michalak M, Podsedek A, Glinka R. Antioxidant capacity and phenolic compounds of Hippophae rhamnoides L. and Vaccinium oxococcos L. glycolic extracts. Fitoterapii. 2016;1:33-8.

[188] Adamczak A, Buchwald B, Kozlowski J. The effect of thermal and freeze drying on the content of organic acids and flavonoids of European craneberry (Oxycoccus palustris Pers.). Herba polonica. 2009;55(3):94-102.

[189] Tikuma B, Liepniece M. Effect of meteorological conditions on large cranberry (Vaccinium macrocarpon Ait.) variety 'Stevens' flowering phenological phases, Zinatniski praktiska konference Lidzsvarota Lauksaimnieciba, Lelgava, Latvia 19-20 February; 2015:166-71.

[190] Buttler A, Robroek BJM, Laggoun-Défarge F, Jassey VE, Pochelon C, Bernard G, Delarue F, Gogo S, Mariotte P, Mitchell EAD, Bragazza L. Experimental warming interacts with soil moisture to discriminate plant responses in an ombrothropic peatland. Journal of vegetation Science. 2015;26(5):964-74.

[191] Klamkowski K, Borowska W, Treder W, Tryngiel-Gac A, Krzewinska D. Effect of mycorrhizal inoculation on photosyntetic activity and vegetative growth of cranberry plants grown under different water regimes. Acta Horticulturae. 2009;838:109-13.

[192] Lacramioara O, Ciprian M. Antioxidants content in Empetrum nigrum fresh and dried fruits. Iran Journal of Public Health. 2016;45(2):263-5.

[193] Angers-Blondin S, Bodreau S. Expansion dynamics and performance of the dwarf shrub Empetrun hermaphroditum (Ericaceae) on a subarctic sand dune system, Nunavik (Canada). Arctic, Antarctic, and Alpine Research. 2017;49(2):201-11.

[194] Boonstra R, Krebs CJ, Cowcill K. Responses of key understory plants in the boreal forests of western North America to natural versus anthropogenic nitrogen levels. Forest Ecology and Management. 2017;401:45-54.

[195] Stuiver BN, Gundale MJ, Wardle DA, Nilsson MC. Nitrogen fixation rates associated with the feather mosses Pleurozium schreberi and Hylocomium splendens during forest stand development following clear cutting. Forest Ecology and Management. 2015;347:1309. 
[196] Grau O, Rautio P, Heikkinen J, Saravesi K, Kozlov MV, Markkola A. An ericoid shrub plays a dual role in recruiting both pines and their fungal symbionts along primary succession gradients. Oikos. 2010;119(11):1727-34.

[197] Nilsson MC, Zackrisson O, Sterner O, Wallstedt A. Characterisation of the differential interference effects of two boreal dwarf shrub species. Oecologia. 2000;123(1):122-8.

[198] Bråthen KA, Fodstad CH, Gallet C. Ecosystem disturbance reduces the allelopathic effects of Empetrum hermaphroditum humus on tundra plants. Journal of Vegetation Science. 2010;21(4):786-95.

[199] Koizumi T, Nara K. Communities of putative ericoid mycorrhizal fungi isolated from alpine dwarf shrubs in Japan: Effects of host identity and microhabitat. Microbes and Environments. 2017;32(2):147-53.

[200] Huusko K, Ruotsalainen AL, Markkola AM. A shift from abuscular mycorrhizal to dark septate endophytic colonization in Deschampsia flexuosa roots occurs along primary successional gradient. Mycorrhiza. 2017;27(2):129-38.

[201] Kim KC, Kang KA, Zhang R, Piao MJ, Heo YJ, Chae SW, Kim GY, Moon Jy, Yoo BS, Hyun JW. Risk reduction of ethyl acetate fraction of Empetrum nigrum var. Japonicum via antioxidant properties against hydrogen peroxide-induced cell damage. Journal of Toxicology and Environmental Health. Part A. 2009;72(21/22):1499-508. H2O2

[202] Jurikova T, Mlcek J, Skrovankova S, Balla S, Sochor J, Baron M, Sumczynski D. Black crowberry (Empetrum nigrum L.) flavonoids and their health promoting activity. Molecules. 2016;21:11. Available online: http://www.mdpi.com/journal/molecules, DOI: $10.3390 /$ molecules 21121685

[203] Bae HS, Kim HJ, Jeong DH, Hosoya T, Kumazawa S, Jun MR, Kim OY, Kim SW, Ahn MR. In vitro and in vivo antiangiogenic activity of crowberry (Empetrum nigrum var. japonicum). Natural Product Communications. 2016;11(4):503-6.

[204] Brännäs E, Nilsson MC, Nilsson L, Gallet C, Brännäs K, Berglind R, Eriksson LO, Leffler PE, Zackrisson O. Potential toxic effect on aquatic fauna by the dwarf shrub Empetrum hermaphroditum. Journal of Chemical Ecology. 2004;30(1):215-27.

[205] Laaksonen O, Sandell M, Järvinen R, Kallio H. Orosensory contributing compounds in crowberry (Empetrum nigrum) pressbyproducts. Food Chemistry. 2011;124(4):1514-24.

[206] Ogawa K, Sakakibara H, Iwata R, Ishii T, Sato T, Tgoda T, Shimoi K, Kumazawa S. Anthocyanin Composition and Antioxidant Activity of the Crowberry (Empetrum nigrum) and Other Berries. Journal of Agricultural and Food Chemistry. 2008;56(12):4457-62. DOI, 10.1021/jf800406v

[207] Lavola A, Salonen A, Virjamo V, Julkunen-Titto R. Phytochemical variation in the plant-part specific phenols of wild crowberry (Empetrum hermaphroditum Hagerup) populations. Phytochemistry Letters. 2017;21:11-20. Available online: DOI: 10.1016(j.phytol.2017.05.016

[208] Olofsson J, Beest M, Ericsson L. Complex biotic interactions drive long-term vegetation dynamics in a subarctic ecosystem. Philosopical Transactions of The Royal Society B. 2013;368:20120486. DOI: 10.1098/rstb.2012.0486

[209] Mod HK, Roux PC le, Luoto M. Outcomes of biotic interactions are dependent on multiple environmental variables. Journal of Vegetation Science. 2014;25(4):1024-32.

[210] Shevtsova A, Haukioja E, Ojala A. Growth response of subarctic dwarf shrubs, Empetrum nigrum and Vaccinium vitis-idaea, to manipulated environmental conditions and species removal. OIKOS. 1997;78:440-458.

[211] Peñuelas J, Prieto P, Beier C, Cesaraccio C, Angelis P de, Dato G de, Emmet BA, Estiarte M, Garadnai J, Gorissen A, Lang EK, KröelDulay G, Llorens L, Pellizzaro G, Riis-Nielsen T, Schmidt IK, Sirca C, Sowerby A, Spano D, Tietema A. Response of plant species richness and primary productivity in shrublands along a north-south gradient in Europe to seven years of experimental warming and drought; reductions in primary productivity in the heat and drought of 2003. Global Change Biology. 2007;13(12):2563-81.

[212] Bienau MJ, Eckstein RL, Otte A, Durka W. Clonality increases with snow depth in the arctic dwarf shrub Empetrum hermaphroditum. American Journal of Botany. 2016;193(12):2105-14.

[213] Buizer B, Weijers S, Bodegom PM van, Alsos IG, Eidesen PB, Breda J van, Korte M de, Rijckevorsel J van, Rozema J. Range shifts and global warming: Ecological responses of Empetrum nigrum L. to experimental warming at its northern (high Arctic) and southern (Atlantic) geographical range margin. Environmental Research Letters. 2012;7(2):9. DOI: 10.1088/1748-9326/7/2/025501

[214] Manninen OH, Tolvanen A. Sexual reproduction of clonal dwarf shrubs in a forest-tundra ecotone. Plant Ecology. 2017;218(6):63545.

[215] Rixen C, Dawes MA, Wipf S, Hagedorn F. Evidence of enhanced freezing damage in treeline plants during six years of $\mathrm{CO}_{2}$ enrichment and soil warming. Oikos. 2012;121(10):1532-43.

[216] Keuper F, Dorrepaal E, Bodegom PM van, Logtestijn R van, Venhuizen G, Hal J van, Aerts R. Experimentally increased nutrient availability at the permafrost thaw front selectively enhances biomass production of deep-rooting subarctic peatland species. Global Change Biology. 2017;23(10):4257-66.

[217] Parker TC, Subke JA, Wookey PA. Rapid carbon turnover beneath shrub and tree vegetation is associated with low soil carbon stocks at a subarctic treeline. Global Change Biology. 2015;21(5):2070-81.

[218] Inga B, Danell Ö. Traditional ecological knowledge among Sami reindeer herders in northern Sweden about vascular plants grazed by reindeer. Rangifer. 2012;32(1):1-17. 
[219] Väisänen M, Martz FR, Kaarlejärvi E, Julkunen-Tiitto R, Stark S. Phenolic responses f mountain crowberry (Empetrum nigrum ssp. hermaphroditum) to global climate change are compound specific and depend on grazing by reindeer (Rangifer tarandus). Journal of Chemical Ecology. 2013;39(11/12):1390-9.

[220] Barthelemy H, Stark S, Kytöviita MM, Olofsson J. Grazing decreases N partitioning among coexisting plant species. Functional Ecology. 2017;31(11):2051-60.

[221] Manninen $\mathrm{OH}$, Tolvanen A. N-fertilization and disturbance impacts and their interaction in forest-tundra vegetation. Plant Ecology. 2013;214(12):1505-16.

[222] Ylisirniö AL, Allèn A. Plant communities of Fennoscandian subarctic mountain ecosystems 60 years after human disturbance. Arctic, Antarctic and Alpine Research. 2016;48(3):469-83. DOI: 10.1657/AAAR0015-068

[223] Wardle DA, Jonsson M. Long-term resilience of above and belowground ecosystem components among contrasting ecosystems. Ecology. 2014;95(7):1836-49.

[224] Aerts R. Nitrogen-dependent recovery of subarctic tundra vegetation after simulation of extreme winter warming damage to Empetrum hermaphroditum. Global Change Biology. 2010;16(3):1071-81.

[225] Ylänne H, Stark S, Tolvanen A. Vegetation shift from deciduous evergreen dwarf shrubs in response to selective herbivory offsets carbon losses: Evidence from 19 years of warming and simulated herbivory in the subarctic tundra. Global Change Biology. 2015;21(10):3696-711. 